\title{
Opting-out of the social contract: Tax morale and evasion
}

\author{
Néstor Castañeda ${ }^{1}$, David Doyle ${ }^{2}$, and Cassilde Schwartz ${ }^{3}$ \\ ${ }^{1}$ University College London \\ ${ }^{2}$ University of Oxford \\ ${ }^{3}$ Royal Holloway, University of London
}

\begin{abstract}
We examine the individual-level determinants of tax morale in low-capacity states, specifically Latin American countries, where the social contract is often perceived as fractured. We argue that individuals in such states perceive the social contract as an agreement to which they can opt in or opt out. Those who choose to opt out prefer to substitute state-provided goods for private providers, rather than pay for public goods through taxes or free-ride to receive those goods. Through a list experiment conducted in Mexico City, we demonstrate that willingness to evade taxes is highest when individuals have stepped outside of the social contract. More traditional indicators of reciprocity - such as socio-economic status and perceptions of corruption are not significant. We bolster our experimental results with observational data from seventeen Latin American cities; those with access to employer-sponsored insurance are more willing to evade tax.
\end{abstract}




\section{Introduction}

At the center of every functioning state is some form of social contract. This is, in essence, an agreement between citizens and the state. The state is tasked with providing public goods, and in return, citizens willingly cede liberty and taxes to the state (Rousseau, 1920). In theory, the bilateral nature of this contract is naturally self-reinforcing. On the one hand, the state cannot provide public goods without sufficient tax revenue. On the other hand, tax morale rests on the foundation of a strong social contract. Indeed, Margaret Levi (1989, p. 52-53) maintains that tax compliance thrives where "taxpayers have confidence that (1) rulers will keep their bargains and (2) the other constituents will keep theirs." Taxpayers comply with their end of the social contract when they perceive an honest, responsible state and an engaged, conscientious citizenry.

While the state's ability to provide public goods has received considerable attention in academic literature (e.g Kurtz, 2013; McGuire, 2014; Bird and Zolt, 2015; Soifer, 2015), the individual-level dimension of the social contract, notably tax morale, has generated only limited research thus far (e.g. Luttmer and Singhal, 2014; Kuziemko et al., 2015; Duch and Solaz, 2015; Ballard-Rosa et al., 2017) and remains largely unexplored in developing countries (Torgler, 2005; Bergman, 2010; Ortega et al., 2016). Indeed, the literature largely neglects the fact that the conditions of a functioning social contract often do not hold in developing or low-capacity states. In such states, public goods provision is often poor, management of public funds is often corrupt or inefficient, and tax evasion is historically high. In these contexts, where the social contract appears fractured, is it not clear what drives citizens to maintain their end of the bargain or, specifically, what drives variation in their willingness to underwrite the arrangement through the payment of taxes.

Tax morale in low-capacity states remains largely unexplored, with some significant exceptions. Bergman (2010), for example, suggests that levels of enforcement, together with reciprocity, are especially important in low-capacity states. Bodea and LeBas (2016) argue that, in the absence of strong enforcement, pro-compliance norms are a function of social 
context, which can act as a substitute for poor quality in state service provision. These theories, while important, struggle to account for individual-level differences where context is held constant, and more importantly, they neglect to consider the agency that citizens exert over the social contract.

This paper examines the individual-level determinants of tax morale in low-capacity states, specifically Latin American countries, where norms of tax compliance are weak and public goods provision is often poor. We argue that individuals in such states perceive the social contract as an agreement to which they can opt in or opt out. If individuals believe that their government can provide public goods efficiently and successfully, relative to private providers, they are more likely to fulfill their end of the contract by paying tax. However, individuals may also opt out of the social contract - in doing so, they take actions to reduce their dependence on state-provided goods and also evade taxes. To neatly capture this idea of opting in and out of the social contract, we focus specifically on the divergence in attitudes towards tax compliance among Latin American citizens who opt out of the public system and purchase private health insurance in comparison to those who remain in the public system.

The primary test of our argument is based on data from an original survey experiment fielded in Mexico. Mexico suffers from high rates of tax evasion: income tax evasion rates are higher than $80 \%$ among small firms, corporate income tax evasion rates are decreasing but still higher than 25\%, and VAT evasion rates are higher than 20\% (Gómez Sabaini and Jiménez, 2012). In 2015, tax evasion in Mexico represented about 3\% of GDP (ECLAC, 2017) and official estimates suggest that personal tax evasion in Mexico fluctuated between $15 \%$ and 19\% between 2004 and 2012 (Fuentes Castro et al., 2013). Individual-level survey data from the AmericasBarometer indicates that, while in general, the attitudes of citizens towards their state is poor, there is notable heterogeneity in these attitudes (Romero et al., 2015). Observational studies on tax compliance however, will likely suffer from social desirability bias, given the sensitive nature of questions about tax evasion (Bradburn et al., 1978). Therefore, we use a list experiment to elicit willingness to evade taxes. 
We find robust evidence that tax morale is lowest among individuals who have stepped outside of the social contract (out of the welfare state) and, instead, opt for private providers. Among those who opt out, roughly $20 \%$ to $30 \%$ express a willingness to evade taxes. Meanwhile, we find limited support for alternative hypotheses on reciprocity. Specifically, we do not find that individuals are more willing to evade taxes when they are wealthy or perceive higher rates of corruption. These findings suggest that individuals do not simply evade taxes when the expected benefits are low; individuals evade taxes after they distance themselves from state-provided goods and opt for privately provided substitutes. When we explore this argument in a larger comparative setting, with data from seventeen Latin American cities, we find further evidence that opting out is a key driver of tax morale. This evidence suggests that those with access to employer-sponsored insurance, or who are independent from state social security, are much more likely to report a willingness to evade taxes.

This paper makes a number of contributions. It has implications for work on state capacity more generally (Kurtz, 2013; Soifer, 2015) together with work on the shape and evolution of tax structures across Latin America (e.g. Centeno, 1997; Wibbels and Arce, 2003; Ardanaz and Scartascini, 2013; Hart, 2010; Schneider, 2013; Bird and Zolt, 2015; Fairfield, 2015; Castañeda, 2017; Castañeda and Doyle, 2019). More specifically, we contribute to the burgeoning literature on the individual-level determinants of tax compliance (e.g. Bergman, 2010; Luttmer and Singhal, 2014; Kuziemko et al., 2015; Duch and Solaz, 2015; Ballard-Rosa et al., 2017) by focusing our attention on states where the benefits of paying taxes are not self-evident and, often, not desired. The importance of examining tax morale under such conditions cannot be overstated. It is in these cases where taxes are most necessary, as public goods are in greatest need of improvement, but at the same time, tax morale is most precarious.

The paper is organized as follows. The first section discusses the literature on state capacity and connects it to the scholarly debate on tax morale, before we present our argument. The second section presents our research design. In particular, we discuss the advantages of 
using population-based list experiments for the study of tax compliance. The third section presents the results of the list experiment we fielded in Mexico City to evaluate the effect of reciprocity on tax morale. We then examine a larger comparative set of data from seventeen Latin American cities to further bolster our results. Our final section concludes.

\section{Taxation, Reciprocity, and the Social Contract}

Although variation in state capacity has long been of interest to researchers, especially in the Latin American context (e.g. O'Donnell, 1993), recently there has been a renewed interest

in the historical institutional roots of state capacity. Rejecting the bellicose accounts of European state formation (e.g. Tilly, 1992), these neo-institutionalist accounts emphasize key junctures in Latin American history, which have shaped the means by which centralized state building processes, which incorporated previously peripheral or 'brown' areas (O'Donnell, 1993), were able to occur successfully (e.g. Kurtz, 2013; Soifer, 2015). In this work, state capacity is conceptualized at the macro-level as institutional power - that is, the ability of the state to induce citizens and organizations within its borders to pay tax (e.g. Kurtz, 2013). This macro-level will be endogenous to the micro-level dimension of state capacity, manifest in the perceived legitimacy of the state by its citizens combined with their willingness to pay these taxes and serve in the military (Kurtz, 2013; Bird and Zolt, 2015, p. 3). In essence, state capacity, as understood in this sense, is a contractarian bargain between the state and its citizens - a social contract (Rousseau, 1920). The state provides public goods, and in turn, citizens are willing to pay tax to facilitate this exchange.

Within the Latin American context, most work has focused on explanations for the variation in the provision of public goods, which is notoriously uneven (e.g. O'Donnell, 1993; McGuire, 2014). However, some work has recently begun to focus on the other side of the equation - taxation - and the often uneven and regressive form that taxation assumes across the region (e.g. Wibbels and Arce, 2003; Hart, 2010; Ardanaz and Scartascini, 2013; 
Schneider, 2013; Fairfield, 2015; Bird and Zolt, 2015; Castañeda, 2017; Flores-Macías, 2018; Castañeda and Doyle, 2019). Most of this burgeoning literature has focused on the macrolevel determinants of taxation and cross-country variation in Latin America more generally.

Literature on the micro-level dimension of the social contract - that is, the willingness of citizens to pay tax and engage in a reciprocal exchange with the state - has begun to coalesce around a number of explanations for individual tax morale. Recent work has demonstrated that willingness to pay tax is conditioned by individual personality traits, such as honesty, positive self-image, national pride, and democratic values (Luttmer and Singhal, 2014; Dwenger et al., 2016) and observable factors such as individuals' position in the income spectrum (Duch and Solaz, 2015). The literature on tax compliance also highlights the relevance of peer effects for tax morale (Frey and Torgler, 2007; Luttmer and Singhal, 2014). According to this literature, individuals may wish to conform to the behavior of relatives, close friends, or acquaintances and so therefore, peer compliance directly affects individual willingness to pay taxes (Castro and Scartascini, 2015; Carrillo et al., 2017; Del Carpio, 2014).

One key explanation centers on the threat of sanction for evading taxes (see Allingham and Sandmo, 1972; Slemrod, 2018). Luttmer and Singhal (2014), in their review of the stateof-the-art, indicate that the threat of punishment appears to have a more robust effect on tax compliance in comparison to all other explanations. Bergman (2010) however, suggests that legal sanctions are insufficient to motivate compliance in Latin America. He argues that tax evasion is more rampant in Argentina than Chile because taxpayers in Argentina do not believe that evasion will be effectively punished. Low levels of capacity to pursue evasion through legal mechanisms means that taxpayers may not perceive threats of sanction as realistic, so these threats may not dominate individual decisions about compliance. Other considerations will become important.

Behind much of the literature on individual tax morale is one such consideration: the individual's perception of reciprocity (Frey and Torgler, 2007; Daude et al., 2013; Castro 
and Scartascini, 2015; Ballard-Rosa et al., 2017; Carrillo et al., 2017; Cullen et al., 2018). Reciprocity refers to the belief among citizens that in paying taxes, the government will provide some tangible public good in return, and that the government can provide this good efficiently and successfully. Building on the insights of Levi (1989), it is widely established that the decision not to free-ride is under-girded by a strong element of rational calculation; citizens are quasi-voluntarily compliant because they believe that they are benefiting from the tax contract. As Levi (1989) contends, "without a perceived benefit, there is absolutely no reason for a rational actor even to consider assuming the costs of taxation" (p. 56). Quasi-voluntary compliance can be established however, not only when citizens perceive that they are receiving benefits from their fiscal contract with the state, but also when rulers can demonstrate that the tax public goods provision is efficient or fair (see also Bergman, 2010).

Where citizens believe that paying taxes to the government results in some direct and valuable reciprocal benefit for them personally, their willingness to pay taxes will be higher. Individuals will weigh the marginal utility they derive from public goods funded by their personal taxes, versus the return they would receive if they were to pay for this public good privately. This will inevitably be shaped by their perceptions of the quality of this public good and how efficient and capable state provision actually is (Daude et al., 2013; Kuziemko et al., 2015; Ortega et al., 2016).

Consider the case of Britain's first income tax introduced in 1799. Quasi-voluntary tax compliance was engendered because the British government assured its citizenry that it would use these funds for the stated purpose of not only fighting the Napoleonic Wars, but also doing so successfully. As Levi argued, the government provided assurances that everybody would pay their fair share and that tax collectors would be honest; "assurances of progressivity, protections of privacy, and public confidence that there would be little administrative waste, corruption, or mismanagement were the prerequisites, the conditions, for quasi-voluntary compliance" (Levi, 1989, p. 138). Concerns about the return in public 
goods, fairness, and efficiency, remain crucial determinants of tax morale, over two hundred years later. In short, "quasi-voluntary compliance rests on reciprocity" (Levi, 1989, p.69). More recently Scheve and Stasavage (2016) argue that, after the two world wars, marginal tax rates (and compliance) increased in the UK and the US because there was a political consensus to promote compensatory/redistribution mechanisms.

As a consequence, ever since Margaret Levi's seminal Of Rule and Revenue (Levi, 1989), the importance of beliefs about reciprocity have been central to the literature. Bergman (2010), Doerrenberg and Peichl (2013), Beramendi and Rehm (2016) and Ballard-Rosa et al. (2017) have all subsequently demonstrated that the willingness to pay taxes is conditioned upon the degree to which individuals perceive public goods provision to be fair, while Daude et al. (2013), Kuziemko et al. (2015) and Ortega et al. (2016) have focused on how tax morale is shaped by whether or not citizens believe the government has the ability to effectively deliver public goods. Others have emphasized the importance of whether citizens believe they will receive some form of reciprocal benefit in return for paying tax (Daude et al., 2013; Castro and Scartascini, 2015; Carrillo et al., 2017; Ballard-Rosa et al., 2017) and there is also a small body of evidence indicating that the payment of tax can encourage citizens to be more willing to hold their government to account, at least in Indonesia and Uganda (Paler, 2013; Martin, 2014).

The central point to take from this handful of studies is that the success of the social contract, and tax morale from the perspective of individual citizens, is predicated upon notions of reciprocity. That is, citizens will be wiling to pay tax if they believe their state has the ability to provide effective and fair public goods from which they will benefit.

\subsection{Tax Morale and Opting Out}

Our argument builds directly on this work. We expect that the willingness to pay tax will be a function of reciprocity, such that tax morale will be highest among those who expect to benefit personally from public goods. However, we maintain that reciprocity might operate 
differently in low-capacity states than existing scholarship would suggest. In low-capacity states, where public services may be underfunded or perceived as poor quality, citizens are not passive surveyors of the marketplace who pay taxes for public goods or who free-ride to receive those goods. Indeed, the notion of free-riding has limited traction in contexts where: 1) citizens are not necessarily eager to obtain access to state-provided public goods, which are often perceived as under-funded or inferior; 2) it is not widely assumed that other citizens are contributing their share of taxes to those goods; and 3), the state has limited capacity to properly enforce taxation. In such conditions, citizens may be more hesitant to abide by their end of the social contract, as it appears that the state and fellow citizens are not abiding by theirs.

At the same time, tax morale does not depend exclusively on the perceived quality of public goods, but also on the relative abundance of private substitutes for under-provided public goods (Cowell and Gordon, 1988). Unlike highly developed welfare states (where private options are only for the very rich and the private market is very small), in weakly developed welfare states, many private options have flourished to replace public health services, education, and even security (Segura-Ubiergo, 2007). In these contexts, private substitutes for public goods could be highly competitive and affordable. Even low income individuals have private options available.

Because of the fragile nature of the social contract and the abundance of outside alternatives, we need to rethink how individual taxpayers in low-capacity states conceptualize the social contract and the impact of this on tax evasion. We argue that individuals in such contexts may consider the option to opt out of this tenuous bargain with the state. Rather than using what they perceive as low quality services, and receiving those goods by either paying taxes or free-riding, they may substitute public goods with privately provided alternatives. Because these individuals prefer not to take advantage of public goods, they are consequently less willing to fund those goods through the payment of taxes. And given that the threat of sanction may not always be credible in low capacity contexts (e.g. Bergman, 
2010) opting out of the tax contract may be a real and relatively low risk option. As such, we argue that tax morale is a function of the individual's decision to remain in contract with the state or to opt out, a decision that will be contingent on state capacity. ${ }^{1}$ Where the state has greater capacity to provide public goods of high quality, then the incentive to opt out and pursue private alternatives to these public goods will not be as large. In contrast, where the state has lower capacity to provide public goods, the incentive to opt out will be higher, and the incentive to pay taxes lower.

Similar to existing research on reciprocity, we expect that income and self-interest will condition preferences for taxation (e.g. Rueda and Stegmueller, 2016). While we anticipate that tax morale will be lowest among individuals - at any level of income - who deliberately opt out from state-provided services, we do not necessarily expect the size of this effect to be consistent across all income groups. Wealthier individuals, who can access high quality private alternatives to public goods, are likely to have lower tax morale. Poorer individuals, particularly in contexts with truncated and regressive public goods provision, are also likely to have low tax morale. Such individuals may be forced to opt out because of deficiencies in the public goods they do receive (see Cotlear et al., 2015), or they may prefer to rely on a charity sector that effectively replaces state provision. In contrast, middle income groups, which have traditionally been fully incorporated into functioning contributory public goods regimes in Latin America, are likely to exhibit slightly higher tax morale among those who opt out. For individuals in this group, the public goods they receive are probably of high quality and generally better than the alternatives they could afford via private provision. Nonetheless, as individuals view taxes as part of a social contract in which tax payments are made in exchange for services provided by the state (Daude et al., 2013; Castro and Scartascini, 2015; Beramendi and Rehm, 2016; Ortega et al., 2016), we expect that those who do opt out of public goods provision will have lower tax morale. ${ }^{2}$

\footnotetext{
${ }^{1}$ Table A.7 in the appendix provides some empirical evidence that opting out is indeed contingent on state capacity.

${ }^{2}$ There will also be those individuals who continue to use state provided services, but who also evade tax - the free-riders. We are not explicitly interested in this group and do not capture them in our empirical
} 
To illustrate our theory of opting out, we will consider a classic example: healthcare. If an individual perceives state provided health care to be of high quality, as well as easy and efficient to access, then it is not hard to imagine that this individual would be more willing to pay tax to fund this system. An individual who perceives state provided health care to be of poor quality, inefficient, costly and difficult to access, relative to private providers in the market, would probably forbear taxation and the social contract. Rather than free-ride for what is deemed an inferior service, she is likely to use her money to purchase private health care instead.

This is particularly pertinent for Latin America, where there is significant variation in the manner that welfare and tax regimes have evolved. There is even a great deal of heterogeneity among citizens within the same state in the degree to which they have been incorporated into a functioning social contract. Some Latin American welfare regimes, which are mostly funded by contributory taxation schemes (McGuire, 2014), are regressive and narrow in their focus, mainly because they evolved in response to the concentration of risk among a particular sector of the labor force during the period of import substitution industrialization (Wibbels and Ahlquist, 2011). The coverage and quality of the delivery of public goods by the state has been further undermined by a region-wide move towards the privatization of social and health insurance institutions throughout the 1990s (Brooks, 2009).

In turn, this dynamic has had an endogenous effect on the willingness of citizens to engage with the state. Recent evidence suggests that in some Latin American countries, citizens have increasingly decided to opt out of the social contract (Ferreira et al., 2012). This has largely been attributed to newly emerging middle class groups, either because they have traditionally not been incorporated into the state or because of a general perception that the quality of public goods provision is poor and sub-standard. They send their children to private schools, employ private security guards, and purchase private social insurance cover (Ferreira et al., 2012). They are not willing to enter into a social contract with the state analysis. 
simply because they believe they a) do not receive reciprocal benefits from the state or b) that the quality of public goods provision is so poor that they are better off seeking private solutions.

We focus on private health insurance as a good proxy for the sense of reciprocity we are interested in here. We think that private insurance, particularly in Latin America, can succinctly capture the type of cost-benefit calculation we discussed above. These are citizens who choose to pay for private health care over, or in addition to, publicly-provided health goods, and the assumption is that they do so because they perceive public provision to be inferior to private provision. We expect that their willingness to engage in a reciprocal social contract with the state will be lower than those who utilize state-provided public goods.

Of course, it is possible that citizens might use private health care, yet still rely on the state for other types of public goods, such as security. For example, Rueda and Stegmueller (2016) demonstrate that wealthy individuals in highly unequal regions of Europe are more likely to support redistribution, compared to the wealthy in more equal regions of Europe. Support for redistribution is due to the externalities of inequality; wealthy individuals believe that higher inequality is more likely to result in them becoming victims of crime, so they perceive redistribution as a means to mitigate security risks. In unequal, low capacity states, however, the dynamic is likely to be different. In Mexico, for example, Flores-Macias and Sánchez-Talanquer (2019) demonstrate that those with the highest levels of concern with crime are less willing to contribute more income in taxes. They argue that "individuals would rather not commit additional resources towards state institutions considered weak, ineffective or corrupt" (p. 11). In Colombia, Flores-Macías (2014) has argued that it was possible to raise taxes among the elite only because the elite's perception of the government's provision of public safety improved. In low capacity states therefore, we believe that opting out of one public good, such as state health care, is indicative of a general sentiment about the state's inability and lack of capacity to provide reasonable and effective public goods in 
other areas. ${ }^{3}$ In essence, we are testing the degree to which citizens are willing to opt out of the social contract. ${ }^{4}$

\section{Research Design}

Our study is one of the first to use list experiments to explore tax morale in developing countries (see also Fergusson et al., 2017). Our empirical analysis is based on an original survey with a representative sample of a large, urban center in a developing economy. Furthermore, our data are not limited to outcome data on tax revenue; we use list experiments to elicit willingness to evade taxes, a technique that has been found to provide more accurate estimates than self-reports for a wide range of sensitive topics (Blair and Imai, 2012; Glynn, 2013).

Our survey was fielded in 2017, and it consists of 1,100 face-to-face interviews in Mexico City. The surveys were conducted on tablets using the Qualtrics off-line application to allow for complete randomization and customization. Our sample was drawn from a sampling frame provided by the Mexican statistics office (Instituto Nacional de Estadística y Geografía - INEGI), managed by the local polling firm that implemented our survey (Beltran, Juarez y Asociados - $B G C$ ), and includes individuals from all levels of income.

The case of Mexico is particularly relevant for the study of tax compliance in developing countries. Mexico is ranked 35th out of 35 OECD countries in terms of tax-to-GDP ratio. Total tax revenue in Mexico was only 16.2\% of GDP in 2017 and has increased only four percentage points in the past 17 years (OECD, 2019). In fact, the tax burden in Mexico is one of the lowest in Latin America (OECD, 2019), and it is also quite low in comparison with countries of similar levels of economic development in other regions of the world. Tax evasion

\footnotetext{
${ }^{3}$ Public health insurance in Mexico is particularly useful in this regard as each public insurance subsystem has evolved to include other aspects of social security and as such, public health cover in Mexico is very much intertwined with wider public goods provision.

${ }^{4}$ Many citizens, particularly in contexts of universal public goods provision, will still have access to the state system and yet purchase additional private insurance. By choosing to pay for private insurance, they clearly view the public system as deficient.
} 
is one of the main determinants of Mexico's poor fiscal performance. In 2015, the federal government lost around US $\$ 1.4$ billion for VAT evasion alone (ECLAC, 2017). Additionally, the Mexican tax base is limited because a significant proportion of the economically active population remains in the informal labor market; around 58\% according to the 2014 Mexican employment survey (Alcaraz et al., 2015).

But most importantly, simple measures of intrinsic attitudes and beliefs about reciprocity are also quite low in Mexico. For example, the results of the most recent AmericasBarometer survey in Mexico show that $83 \%$ of Mexicans think that corruption is a generalized problem; about $53 \%$ have little, or very little, trust in the federal government; only $8 \%$ positively evaluate the role of the government in fighting corruption; and only $34 \%$ are satisfied with democracy (Romero et al., 2015).

\subsection{Eliciting Preferences for Tax Evasion}

Our dependent variable, tax morale, presents a methodological challenge for analysis. Traditionally, scholars measure tax morale by asking people if they are willing to pay taxes or if they are willing to pay additional taxes as a response to changes in policies. From this perspective, scholars seek to evaluate individual responses to policy or informational stimulus (e.g. Castro and Scartascini, 2015; Ortega et al., 2016). Some other studies focus on ethical or moral issues and the individual propensity to evade taxes (Luttmer and Singhal, 2014). From this point of view, it seems more important to understand the mechanisms that explain why individuals cheat or find cheating on taxes justifiable (e.g. Duch and Solaz, 2015). In any case, these type of direct questions on tax practices are quite susceptible to social desirability bias.

We use a list experiment to measure individual willingness to pay taxes (see Blair and Imai, 2012; Glynn, 2013). List experiments enable us to measure support for taboo or illicit behaviors while, at the same time, protecting respondents' anonymity (e.g. De Jonge and Nickerson, 2014). The list experiment procedure is straightforward. Respondents are 
presented with a hypothetical scenario, and they are instructed to reveal (only) the number of responses they would support, but not which responses they would consider. Half of the respondents are randomly assigned to a control group, and the other half to a treatment group. The only difference between these two groups is the inclusion of a theoretically important sensitive item, which is only included in the treatment list.

It might be argued that a list experiment is not necessary to measure tax evasion, given that Mexican citizens would not fear any punishment for reporting a willingness to evade taxes. However, when we compare self-reported tax compliance with actual tax compliance, we see an interesting trend: Mexican citizens tend to over-report willingness to evade taxes. In a 2013 survey conducted by the Servicio de Administración Tributaria (SAT), as many as $33 \%$ of Mexicans said it was justifiable to cheat and not pay taxes. For some forms of tax evasion, such as paying in cash to avoid VAT, approximately $65 \%$ believed evasion was justifiable. These estimates are very high, compared to the actual rates of evasion (SAT, 2013). Therefore, we believe that our list experiment closely captures genuine preferences for tax evasion and alleviates the possibility of under- or over-reporting.

In our survey instrument, respondents were shown "a list of [three/four] things that people would do to save money." They were asked: "How many of these things would you consider doing to save money? Your answer must be a number." The enumerator listed three potential control responses: "spend less money on groceries each week," "steal some money," and "look for an additional job." Half of the respondents were randomly assigned to this control group.The other half of the respondents were randomly assigned to the treatment group, to which the survey enumerator displayed the three potential responses listed above as well as a fourth, sensitive item. In this case, the treatment group list included an option to Not pay your taxes.

An alternative to this sensitive item would be a more specific example of tax evasion, such as not paying VAT or personal income taxes. However, our pre-tests indicated that many individuals were confused about specific taxes. They were often uncertain about 
which taxes applied to them or what were the specific strategies that one could use to evade. To avoid such confusion, we elected to use a more generic sensitive item, which was widely understood throughout the subject pool. Under conditions of perfect randomization, the difference between the average number of items in the treatment and control groups represents the percentage of the sample that would support the illegal/sensitive behavior.

The baseline list was specifically designed, based on best practice for list experiments, to ameliorate design effects as well as strategic error on behalf of the respondents (Glynn, 2013). First, it is important that the presence of the sensitive item does not change the composition of the list as a whole (Blair and Imai, 2012). Perhaps an item is somewhat controversial in the context of the baseline list, but appears mild in comparison with the sensitive item in the treatment list. In order to prevent such a design effect, our baseline list includes a lowprevalence item (stealing some money) that is likely considered to be more taboo than the sensitive item. The list was also designed to reduce the probability of strategic misreporting, which can occur if a respondent perceives that her support for the sensitive item is somehow revealed in her answer. We attempted to mitigate this concern by incorporating baseline items that are negatively correlated with one another (Glynn, 2013). Specifically, we expect that the type of person who is hard-working enough to consider looking for an additional job and responsible enough to spend less money on groceries is unlikely to support petty theft.

Before reporting results from the statistical analysis, we will assess the degree to which the list experiment accurately elicited support for tax evasion. We statistically test for design effects using the ict.test function in the $\mathrm{R}$ list package (Imai, 2011). With a Bonferroni correction for multiple testing, our minimum p-values fail to reject the null hypothesis of no design effects for experiments. The response distribution in the control group indicate that we were largely successful in designing a list where few people would fear revealing their support for the sensitive item by supporting all items in the baseline list. Only $4 \%$ of respondents in the control group selected zero items from the list, and only $1 \%$ of the control group selected all items available. This suggests that individuals were not likely to suppress 
their support of the sensitive item for fear of revealing their preferences. Furthermore, the similar proportions of the treatment and control lists lend face validity to the test failing to identity design effects. Taken together, we believe that the list experiment was well designed to capture true preferences.

The list experiment is not the only experimental design that allow survey researchers to measure support for sensitive items. Another viable option - the randomized response technique - tends to result in even less bias (Rosenfeld et al., 2016). Both techniques are vulnerable to strategic error, whereby respondents lie to conceal their preferences, and nonstrategic error, where respondents misunderstand the technique or fail to see how the design maintains their anonymity. For our study, we preferred the list experiment for considerations of non-strategic error. Non-strategic error and difficulties in implementation can be highly problematic, especially in developing country contexts where formal education cannot be taken for granted (Kiewiet de Jonge and Nickerson, 2014; Ahlquist, 2018). We found that the randomized response technique, which requires respondents to have a basic understanding of probability and randomization, was too cognitively arduous for our respondent pool and made it difficult for them to answer questions.

After extensive pre-testing, we incorporated specific implementation accommodations for our list experiment to reduce non-strategic error. First, we devoted a substantial portion of enumerator training to the use and purpose of list experiments. We conducted several mock interviews and highlighted which respondent behaviors were unacceptable. Second, we explained our instructions in greater detail in the survey instrument and specifically stated that the appropriate response would be a numerical sum. Third, we included a dry-run list experiment in the survey instrument, which walked the respondent through a simple example. Finally, we used show-cards to identify the list items and response options, and we specifically instructed enumerators not to read any of the lists aloud unless the respondent required assistance. In the field, enumerators read the prompt, presented the showcard, and the respondents considered the list privately until they gave their answer. 


\subsection{Publicly or Privately Provided Services}

In order to test our main hypothesis on opting out of publicly provided services, we wish to know whether or not respondents substitute or compliment state-sponsored health care for private providers. Since 1983, the Mexican constitution has guaranteed health care to all its citizens, which is provided through a number of different public providers. Individuals have no control over their public provider as affiliation is determined by occupation. Those with private salaried employment (and beneficiaries) have their health care covered by the Instituto Mexicano del Seguro Social (IMSS). Those who work for the federal government are covered by the Instituto de Seguridad y Servicios Sociales de los Trabajadores del Estado (ISSSTE), and there are also additional specific publicly funded insurance schemes for those working in PEMEX and other select state entities. All those without coverage under the programs above, are entitled to coverage with Seguro Popular (SP), which extends publicly funded health insurance to nearly 50 million Mexican citizens (OECD, 2016, p. 57). ${ }^{5}$ Private health insurers and private hospitals also operate widely in Mexico. In fact, with 11.4 publicly owned and 28.6 privately owned hospitals per million population, "Mexico displays the highest ratio of private to public sector facilities across OECD countries" (OECD, 2016, p. 63). Furthermore, the Mexican health system is best understood as a series of health care subsystems. Each major provider of health care, including the four major public providers, IMSS, ISSSTE, PEMEX and Seguro Popular, together with private insurers, operates and owns its own clinics and hospitals. In effect, each one is a distinct health system (OECD, 2016, p. 55).

According to the most recent census data published in 2015, 23.1\% of the covered population had access to services provided by private institutions, $36.8 \%$ to health care services provided by public social security institutions, and $40.1 \%$ to the National System for Social Protection (INEGI, 2010, 2015). The same sources indicate that approximately $17 \%$ of the Mexican population remain unaffiliated to any of these public plans (this figure is 21.5 per

\footnotetext{
${ }^{5}$ Or other area specific targeted programs such as Clínicas de la Ciudad de México.
} 
cent according to the OECD). ${ }^{6}$ It is also important to note that the proportion of users of private health care services is higher in Mexico City where, according to census data, $27.75 \%$ of the population is affiliated to private health insurance schemes (INEGI, 2010). Across the country, most use of private health services is through private insurance and out of pocket spending (see OECD, 2016).

In our questionnaire, we asked respondents whether or not they were affiliated to any of the major public health services (e.g. Instituto Mexicano del Seguro Social (IMSS), Instituto de Seguridad y Servicios Sociales de los Trabajadores del Estado (ISSSTE), Secretaría de Salud, Institutos de Nutrición, Neurología, o Cancerología, Seguro Popular, Clínicas de la Ciudad de México). We also asked them a separate question about their use of private health insurance, as many of those in our sample who opt out with private health insurance are also covered by one of the public insurance schemes. Our main independent variable therefore, is based on the following question: "Do you have any private medical insurance?", where all those who answered yes were coded as 1 , and all those who answered no were coded as $0 .^{7}$

A focus on opting out of public health insurance in Mexico City is particularly useful in this context. In 1943, with the creation of the Ministry of Health, IMSS was founded not only to provide health cover for formal sector workers, but also pensions for old age and disability, insurance against occupational risk and even child care services (OECD, 2016, p. 55). The other social security sub-systems have evolved to provide a similar mix of health care, pensions and other welfare benefits (see OECD, 2016, p. 55). This means that opting out of the public schemes in Mexico, or supplementing cover with private insurance, is a very good indicator of discontent with the state social security system as a whole, given that these sub-systems encapsulate pensions and other welfare benefits.

\footnotetext{
${ }^{6}$ For those unaffiliated and without insurance, there are Red Cross Health Centres in various parts of the state.

${ }^{7}$ It is possible some respondents took this to mean to private out of pocket spending. Even if this is the case, we think this is still a good example of individuals having to opt out and pay for private goods, above and beyond public provision.
} 


\subsection{Other determinants of tax morale}

The literature on the determinants of tax morale is extensive and covers a wide range of hypotheses (Luttmer and Singhal, 2014; Slemrod, 2018). Based on this literature, one can identify several individual-level factors that could potentially explain tax morale (Luttmer and Singhal, 2014; Slemrod, 2018) and in order to control for these alternative explanations, we include several variables in our questionnaires and model specifications.

Objective individual attributes, such as socioeconomic status, education, and position within the labor market, could all shape citizens' willingness to pay taxes. We use the NSE/AMAI index to measure socioeconomic status. The NSE/AMAI index was created by the Mexican Association of Poll Firms (Asociación Mexicana de Agencias de Inteligencia de Mercado y Opinión - AMAI) to classify households based on a battery of items related to the quality of housing, patterns of consumption, and welfare. The NSE/AMAI index is not a measurement of individual income but it provides a standard metric to classify individuals according to their socioeconomic status. The index is commonly used by the INEGI and all survey firms in Mexico. Education is measured on a scale from "no education" to "post-graduate" education. We measure respondents' position in the labor market as a dummy variable, where values of 1 mean that individuals report being employed or seasonally-employed.

We also include two proxies that attempt to capture an individuals' beliefs about reciprocity, or the perception that the government would not squander tax revenue but use it for the public's benefit using a 10-points scale in which respondents assessed the effectiveness of the federal government's role in fighting poverty and reducing corruption. Specifically, we asked, "On a scale from 0 to 10, where 0 is nothing and 10 is a lot, how much money do you think the government spends trying to help the poor?" and "on a scale from 0 to 10 , where 0 is not bad at all, how bad is corruption in your country?" 8 We also included three indicators

\footnotetext{
${ }^{8}$ These two questions are imperfect but useful proxies for whether citizens perceive public goods to be of good quality and fair.
} 
to measure how normative attitudes toward redistribution and inequality shape individual attitudes towards tax evasion. To measure respondents' perceptions about inequality, we asked them, on a scale of 1 to 4, how much they agree or disagree that, "the gap between the income of the bottom $90 \%$ of the population and the top $1 \%$ is too large." Meritocracy is a second and important dimension for any individual assessment about inequality. Therefore, we also asked our respondents, on the same scale of 1 to 4, if they agreed that "economic success is due to your family's social status" and "economic success is due to luck."

Finally, we assessed the role of deterrence and peer effects on tax compliance and preferences. To measure deterrence, we asked our respondents about their perceived probability that their neighbors would be audited or prosecuted if they were evading taxes: "Suppose 10 people in your neighborhood are illegally avoiding paying taxes, how many of these 10 do you think will be caught by authorities?" To measure peer effects - or free-riding - we asked respondents: "Think of your family members and tell me if you believe: they all pay taxes, most pay taxes, some pay taxes, or none of them pay taxes."

\section{Analysis of the Tax Morale List Experiment}

In this section, we will test our theory of tax morale by analyzing our list experiment. First, we estimate the average treatment effect to measure support for tax evasion. Table 1 shows the distributions and average treatment effect for the list experiment. ${ }^{9}$

The difference-in-means between the groups - the average treatment effect (ATE) - may be interpreted as the proportion of respondents who support the sensitive item, which in this case refers to tax evasion. As is shown in Table 1, the mean number of items reported in the treatment list is 0.1742 higher than that of the control list, indicating that approximately $17 \%$ of the sample would have selected the sensitive item (they would not pay their taxes to save money). This difference-in-means is statistically significant, and it appears to be externally valid. Official estimates of individual tax evasion in Mexico indicate that personal

\footnotetext{
${ }^{9}$ In Tables A.1 and A.2, we include balance tests across a wide range of variables.
} 
Table 1: Tax Evasion List Experiment: Descriptive Statistics

\begin{tabular}{lcccc}
\hline \hline & \multirow{2}{*}{ Control Group } & \multicolumn{2}{c}{ Treatment Group } \\
& Frequency & Proportion & Frequency & Proportion \\
\hline 0 items & 22 & $4.00 \%$ & 21 & $3.82 \%$ \\
1 item & 366 & $66.55 \%$ & 309 & $56.18 \%$ \\
2 items & 152 & $27.64 \%$ & 181 & $32.91 \%$ \\
3 items & 6 & $1.09 \%$ & 33 & $6 \%$ \\
4 items & 4 & $0.73 \%$ & 4 & $0.73 \%$ \\
NA & 550 & $\mathbf{1 0 0 \%}$ & $\mathbf{5 5 0}$ & $0.36 \%$ \\
\hline Total & $\mathbf{5 5 0}$ & $\mathbf{1 . 2 6 0}$ & $\mathbf{1 . 4 3 4}$ \\
Mean & ATE $=\mathbf{0 . 1 7 4 2} ; \mathbf{p}-$ value $=\mathbf{0 . 0 0 0 0 0 4 6}$ \\
\hline \hline
\end{tabular}

income tax evasion fluctuated between 15\% and 19\% between 2004 and 2012 (Fuentes Castro et al., 2013).

Next, we are interested in the determinants of tax evasion. What kinds of individuals would be more or less likely to evade? As we argue in Section 2.1, we expect that individuals with private health insurance will be more willing to evade taxes, and this effect will be greater than the effect of other alternative explanations like socio-economic status, deterrence or informational asymmetries.

Table 2 presents multivariate analyses of our list experiment. Each model was estimated as a linear function of treatment assignment times each of the theoretical covariates. The interaction terms between treatment assignment and each covariate indicate the difference between treatment and control groups (the treatment effect) for each unit increase of the variable. For presentation purposes, Table 2 only shows the coefficients of the interaction terms. The full output for each model, which includes the coefficients predicting the item count for the control list, can be found in Table A.3 in the appendix.

Table 2 presents the multivariate results of the list experiment progressively. Model 1 evaluates the effect of private health insurance on individual willingness to evade taxes. Every subsequent model includes socio-economic indicators as control variables and private health insurance as our main variable of interest. Model 2 estimates the effect of additional 
proxies of reciprocity (e.g.perceived government attention to the poor or perceived levels of corruption). Model 3 includes perceptions of inequality and social fairness. Model 4 assesses the effect of deterrence mechanisms and model 5 addresses respondents' reaction to peer effects. Finally, Model 6 combines all of these variables into a full model of tax evasion.

Table 2: List Experiment, linear estimates - willingness to evade taxes

\begin{tabular}{|c|c|c|c|c|c|c|}
\hline & $\begin{array}{c}(1) \\
b /(s e)\end{array}$ & $\begin{array}{c}(2) \\
b /(s e)\end{array}$ & $\begin{array}{c}(3) \\
b /(s e)\end{array}$ & $\begin{array}{c}(4) \\
b /(s e)\end{array}$ & $\begin{array}{c}(5) \\
b /(s e)\end{array}$ & $\begin{array}{c}(6) \\
b /(s e)\end{array}$ \\
\hline Private health insurance & $\begin{array}{c}0.257^{* * *} \\
\quad(0.09)\end{array}$ & $\begin{array}{c}0.233^{* * *} \\
(0.09)\end{array}$ & $\begin{array}{c}0.296^{* * *} \\
(0.09)\end{array}$ & $\begin{array}{c}0.302^{* * *} \\
(0.09)\end{array}$ & $\begin{array}{c}0.194^{* *} \\
(0.09)\end{array}$ & $\begin{array}{c}0.223^{* *} \\
(0.10)\end{array}$ \\
\hline \multicolumn{7}{|l|}{ Socio-economic conditions } \\
\hline Socio-economic status & $\begin{array}{l}0.002 \\
(0.04)\end{array}$ & $\begin{array}{c}-0.003 \\
(0.04)\end{array}$ & $\begin{array}{l}0.028 \\
(0.04)\end{array}$ & $\begin{array}{l}0.006 \\
(0.04)\end{array}$ & $\begin{array}{c}-0.013 \\
(0.04)\end{array}$ & $\begin{array}{l}0.014 \\
(0.04)\end{array}$ \\
\hline Education & $\begin{array}{l}0.004 \\
(0.02)\end{array}$ & $\begin{array}{l}0.004 \\
(0.02)\end{array}$ & $\begin{array}{l}0.005 \\
(0.02)\end{array}$ & $\begin{array}{l}0.002 \\
(0.02)\end{array}$ & $\begin{array}{c}-0.006 \\
(0.02)\end{array}$ & $\begin{array}{r}-0.007 \\
(0.02)\end{array}$ \\
\hline Employed & $\begin{array}{c}-0.029 \\
(0.08)\end{array}$ & $\begin{array}{r}-0.027 \\
(0.08)\end{array}$ & $\begin{array}{r}-0.078 \\
(0.08)\end{array}$ & $\begin{array}{r}-0.047 \\
(0.09)\end{array}$ & $\begin{array}{c}0.000 \\
(0.09)\end{array}$ & $\begin{array}{r}-0.065 \\
(0.09)\end{array}$ \\
\hline
\end{tabular}

Reciprocity proxies

Govt. helps the poor

Perceived level of corruption

Attitudes towards inequality

Inequality gap is too large

Success = family status

Success $=$ hard work

Deterrence and peer effects

Audit risk (neighbors)

$0.025 \quad 0.020$

$(0.02) \quad(0.02)$

Sanction level (neighbors)

0.016

0.039

Peer effects (family)

(0.05)

(0.06)

$0.0710 .126^{* *}$

\begin{tabular}{lcccccc} 
& \multicolumn{3}{c}{} & & $(0.05)$ & $(0.05)$ \\
\hline$N$ & 1,004 & 988 & 928 & 909 & 923 & 775 \\
$R^{2}$ & 0.042 & 0.053 & 0.078 & 0.074 & 0.051 & 0.126 \\
\hline \hline
\end{tabular}

${ }^{*} \mathrm{p}<0.1 ;{ }^{* *} \mathrm{p}<0.05 ;{ }^{* * *} \mathrm{p}<0.01-$ Standard errors in parentheses 
As is clear from Table 2, two of our variables significantly predict willingness to evade taxes: private health insurance and peer effects. In the fully controlled model, $22 \%$ more respondents who have private health insurance would evade paying taxes than their counterparts without private insurance. This effect is robust across all model specifications, and the magnitude of the effect varies between $19 \%$ and 30\%. The significant effect persists even when controlling for socio-economic status, education, and employment. That is, the effect does not emerge because only rich, educated, or employed individuals are likely to purchase private health insurance. The effects are also consistent even when controlling for the respondents' perceptions of reciprocity, attitudes towards inequality, the effects of deterrence mechanisms, and peer compliance effects. In other words, our findings suggest that individuals definitively view taxes as part of a social contract. If citizens have private health insurance, then the perceived reciprocal benefit of the social contract will be lower for this group and they will be more willing to evade taxes.

Additionally, the results presented in Table 2 show that peer effects also have a significant effect on tax evasion, but not through peer pressure - or the so-called pro-social behavior (Fehr and Gächter, 2000). If the knowledge that your close network were complaint in their tax payments made you more compliant through peer pressure, we would find a negative effect between peer effects and tax evasion. However, the coefficient is significant and positive. In other words, believing that your close network is obediently paying their taxes makes you more willing to evade your own payments. This effect more clearly represents free-riding rather than peer pressure. Jointly with the significant effect of private health insurance, the full model indicates that individuals are more willing to evade taxes when they perceive they do not need to pay, either because they do not believe that there is a reciprocal benefit in doing so as they do not depend on government welfare or because they believe they can depend on others to pay. ${ }^{10}$

\footnotetext{
${ }^{10}$ The threat of sanction had no effect. It is possible that the threat of punishment for tax evasion is not fully credible in Mexico City. It is also possible that the questions we asked in the survey were not ideal proxies to capture this.
} 
In other words, our analysis of the list experiment consistently suggests that individuals in Mexico City are 1) highly willing to evade taxes, 2) more willing to evade taxes when they are independent from state-provided health care services, and 3) more willing to evade taxes if they perceive their peers obediently comply.

The key point for our argument is that having private health insurance - i.e. the possibility of opting out from the state - makes an individual more likely to evade taxes, above and beyond their wealth or socioeconomic status. The results presented in Table 2 suggest that, even when controlling for socio-economic status and position in the labor market, individuals who are independent from state provision of public goods are still more likely to evade. These individuals are less likely to evade as free-riders, but rather, as individuals who actively reject state-provided goods.

But is having private health insurance simply indicative of wealth? Are wealthy citizens more likely to opt out of publicly-provided health care services and, at the same time, more willing to evade taxes? If this were the case, the relationship with tax evasion could be easily explained as self-interest. In the analyses that follow, we examine the relationship between private health insurance, socio-economic status, and tax evasion more closely. In Table 3, we can see that about $30 \%$ of the respondents report having private health insurance. This is very similar to official figures, which indicate that, $28 \%$ of residents in Mexico City have some type of private health insurance, or seguro de gastos medicos (INEGI, 2010, 2015).

Table 3: Public or private health insurance by socio-economic status, Mexico City 2017

\begin{tabular}{lccccc}
\hline & \multicolumn{4}{c}{ Socio-Economic Status - AMAI index } & \\
& ABC + & $\mathbf{C}$ & $\mathbf{D}+$ & $\mathbf{D} / \mathbf{E}$ & Total \\
\hline Registered to public health services & 104 & 214 & 144 & 240 & 702 \\
& $(47.49)$ & $(69.48)$ & $(73.10)$ & $(83.62)$ & $(69.44)$ \\
\hline Have private health insurance & 115 & 94 & 53 & 47 & 309 \\
& $(52.51)$ & $(30.52)$ & $(26.90)$ & $(16.38)$ & $(30.56)$ \\
\hline Total & 219 & 308 & 197 & 287 & 1,011 \\
& 100.00 & 100.00 & 100.00 & 100.00 & 100.00 \\
\hline
\end{tabular}

NOTE: Pearson chi-squared $(3)=78.1726 \mathrm{Pr}=0.000$; column percentage in parenthesis. According to the AMAI Index $A B C+$ correspond to higher levels of socioeconomic status, while categories $D+, D / E$ correspond to lower levels of socio-economic status.

Although private health insurance is more prevalent among those with higher levels of 
socio-economic status (category $\mathrm{ABC}+$ ), a significant proportion of individuals - between $16 \%$ and $27 \%$ - with lower levels of socio-economic status (categories D+, D/E) also have access to private health insurance. Private health insurance coverage depends on the level of insurance taken out (basic or comprehensive), so policies are affordable for individuals at different levels of income. We can also see that not all individuals with higher levels of socio-economic status (category $\mathrm{ABC}+$ ) have private health insurance. In fact, about $48 \%$ of them report using public health care services only. This variation is a clear indication that many Mexicans choose not to opt out, even if they can easily afford to do so. Overall, almost 1 in 3 individuals in our sample have access to private health insurance.

In Figure 1, we split the sample between respondents with and without private health insurance and across different levels of socio-economic status. Figure 1 shows that, in general and across different levels of socio-economic status, individuals who have private health insurance are significantly more likely to evade taxes than those without private coverage.

In the right panel, willingness to evade taxes is not statistically significantly for individuals using public health care services. This effect is consistent across different levels of socio-economic status with the exception of individuals in category C. In the left panel, willingness to evade taxes is statistically significant for individuals with private health insurance, although this effect is clearly not linear across the different socio-economic groups. That is, both the very wealthiest and very poorest individuals are likely to evade if they do have private health coverage. Those in $\mathrm{ABC}+$ with private insurance, have access to high quality private alternatives. For the very poorest, we think they are forced to purchase private insurance or pay out of pocket because of deficiencies in the quality of service with Seguro Popular.

For example, Seguro Popular has a precisely defined positive list of available interventions, while IMSS and ISSSTE cover all health needs and interventions (OECD, 2016, p.92). At the same time, 33 per cent of medicines in Seguro Popular cannot be dispensed for lack of stock compared to only 14 per cent for the IMSS (OECD, 2016, p.16). It is likely the case 


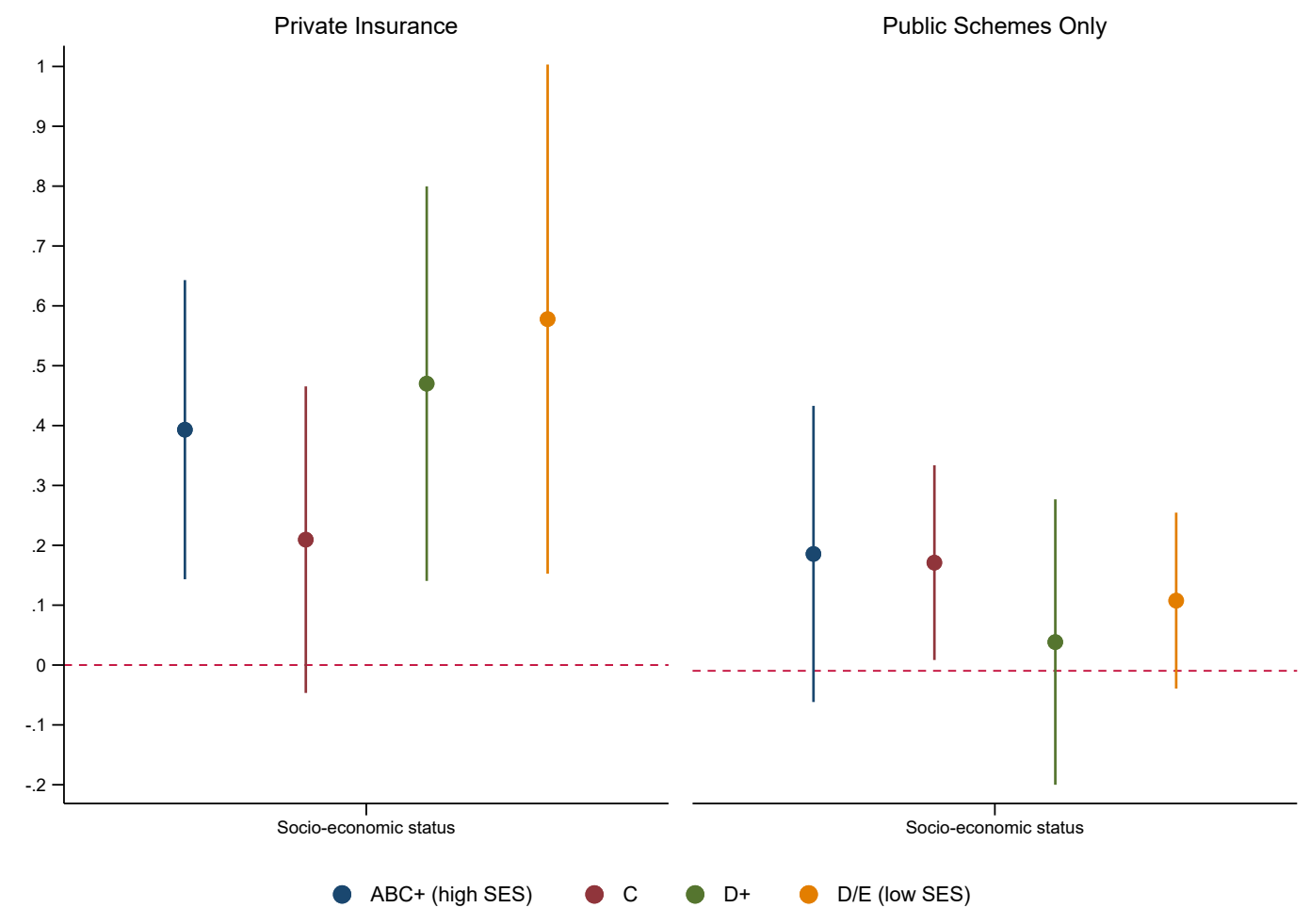

Figure 1: Willingness to evade taxes by type of health care provider and level of socioeconomic status, Mexico City, 2017. Based on list experiment, linear estimators, Table 2.

that those who are affiliated with Seguro Popular and who purchased private insurance did so because of deficiencies in service. They were forced to opt out, and hence their tax morale is lower. ${ }^{11}$

The results presented in Figure 1 therefore, provide empirical evidence that, no matter the level of socio-economic status, there is a divergence between those with private health insurance and those without it. For the most part, it is the willingness, or necessity, to be independent from state services - rather than wealth - what drives tax evasion. ${ }^{12}$

\footnotetext{
${ }^{11}$ Figure A.2 helps to clarify this effect. This figure suggests that individuals seems to be more willing to evade: i) when they are formal workers (i.e., their employers make contributions to the IMSS), and they have enough disposable income to top-up their level of protection with private health insurance; and ii) poor people that fulfill the requirements to use the services provided by Seguro Popular, but can also buy basic private health insurance policies (which is not uncommon because there are affordable policies available in the market).

${ }^{12}$ Figure A.3 in the Appendix show that this divergence does not depend on the occupational composition of the different income groups.
} 


\subsection{Evidence from other Latin American Cities}

In order to test the external validity of our findings, we test similar models of tax morale using data from a large-scale regional survey conducted by the Corporación Andina de Fomento (CAF)-Development Bank of Latin America in 2011 (CAF, 2012). The CAF Survey 2011 is unique in its kind and examines citizen views on tax policy across 17 cities in 9 Latin American countries. The questionnaire includes reasonably similar or equivalent items to the ones we use for our list experiment so we are able to provide some validation for our experimental findings by analyzing non-experimental data in a sample beyond the target population we studied in Mexico.

For the dependent variable, we use a question on willingness to evade taxes: "is it morally justifiable to evade taxes?" This question is a useful proxy to evaluate the respondents' willingness to evade taxes, or at least report a willingness to do so, and allows for a degree of comparability between our findings in the list experiment with this cross-sectional sample. We use both the continuous measure of this variable and a binary categorization in the models below. ${ }^{13}$

Our main independent variable in the list experiment measures whether or not respondents rely solely on state-provided health coverage or whether they also pay for private insurance. Unfortunately, the CAF Survey does not include a directly analogous question. However, it does ask respondents to report if their employers make deductions for private health insurance plans. We wish to capture how the degree of independence from publicly provided health care services shapes the beliefs and attitudes of individuals towards taxation. As such, for all those with private health insurance and who also do not contribute to a public health scheme, we code as 1 , and code all others as 0 . Given the limitations of this measure, we include a second alternative independent variable. This question asked

\footnotetext{
${ }^{13}$ All respondents were asked how justifiable it is to evade taxes on a 1 (totally unjustifiable) to 10 (totally justifiable) scale. For the binary variable, we coded as 1 all those who chose seven and above and coded all others as 0 . The use of a binary dependent variable allows us to model the probability when individuals strongly believe that tax evasion is justifiable.
} 
each respondent whether their employer makes any contribution to their pension or social security funds. Here, all those who answered "no" were coded as 1 and all others as 0 . We think this measure is more useful as it better captures independence from state provided public goods. It is also a broader measure of independence, in that it includes pensions and social security, and helps us to assess the validity of our argument above and beyond health services.

We also included a range of controls to try and proxy for additional hypotheses about the determinants of tax morale. For socio-economic conditions, we use standard metrics of individual reported household income, educational attainment, and employment status. For attitudes towards inequality, we use a question in the survey to measure respondents' awareness and sensitivity to inequality (salience of the issue) and for deterrence, we use a question to measure respondents' perceived probability of being sanctioned by the tax authority ("if you decided to evade taxes ten times, how many of these ten times would you be sanctioned?"). For peer effects, we create a combined measure using two questions that capture respondent's perceived level of tax compliance among both individual citizens and firms (e.g. "From 1 to 10, how many of your fellow nationals dutifully pay their taxes?").

Table 4 presents the results from four different model specifications that regress the independent variables on the respondents' perception that it is justifiable to evade taxes. All models present the estimates from a three-level hierarchical model in which respondents are nested in cities and then in countries. These are simple random intercept model with single residuals for each level and intercept terms randomly varying across cities and countries. Models 1 and 3 are multilevel mixed-effects logit models, while models 2 and 4 are multilevel mixed effects linear models. ${ }^{14}$

Across different model specifications, individuals with employer-sponsored, private health insurance and who also do not contribute to public health schemes, and individuals who are independent of state pensions and social security, are more likely to find tax evasion morally

\footnotetext{
${ }^{14}$ Tables A.5 and A.6 in the appendix present the results of country and city fixed-effects model specifications.
} 
Table 4: Is tax evasion morally justifiable? Latin America, 17 cities

\begin{tabular}{|c|c|c|c|c|}
\hline & $\begin{array}{c}(1) \\
\text { Multi-level } \\
\text { logit } \\
b / s e\end{array}$ & $\begin{array}{c}(2) \\
\text { Multi-level } \\
\text { OLS } \\
b / s e\end{array}$ & $\begin{array}{c}(3) \\
\text { Multi-level } \\
\text { logit } \\
b / s e\end{array}$ & $\begin{array}{c}(4) \\
\text { Multi-level } \\
\text { OLS } \\
b / s e\end{array}$ \\
\hline Private health insurance & $\begin{array}{c}0.479^{* *} \\
(0.24)\end{array}$ & $\begin{array}{l}0.056 \\
(0.16)\end{array}$ & & \\
\hline Independence from public goods & & & $\begin{array}{c}0.327^{* *} \\
(0.14)\end{array}$ & $\begin{array}{c}0.344^{* * *} \\
(0.09)\end{array}$ \\
\hline Household income & $\begin{array}{r}-0.000 \\
(0.00)\end{array}$ & $\begin{array}{r}-0.000 \\
(0.00)\end{array}$ & $\begin{array}{c}-0.000 \\
(0.00)\end{array}$ & $\begin{array}{r}-0.000 \\
(0.00)\end{array}$ \\
\hline Education & $\begin{array}{r}-0.038 \\
(0.03)\end{array}$ & $\begin{array}{c}-0.101^{* * *} \\
(0.02)\end{array}$ & $\begin{array}{r}-0.028 \\
(0.03)\end{array}$ & $\begin{array}{c}-0.083^{* * *} \\
(0.02)\end{array}$ \\
\hline ln the labor market & $\begin{array}{c}-0.943 \\
(1.17)\end{array}$ & $\begin{array}{r}-0.316 \\
(0.90)\end{array}$ & $\begin{array}{r}-0.942 \\
(1.20)\end{array}$ & $\begin{array}{l}0.301 \\
(0.98)\end{array}$ \\
\hline Strong preferences for redistribution & $\begin{array}{c}0.294^{* *} \\
(0.12)\end{array}$ & $\begin{array}{c}0.147^{*} \\
(0.08)\end{array}$ & $\begin{array}{c}0.260^{* *} \\
(0.13)\end{array}$ & $\begin{array}{l}0.087 \\
(0.08)\end{array}$ \\
\hline Perceived probability of sanction & $\begin{array}{l}0.027 \\
(0.02)\end{array}$ & $\begin{array}{c}-0.045^{* * * *} \\
(0.01)\end{array}$ & $\begin{array}{c}0.008 \\
(0.02)\end{array}$ & $\begin{array}{c}-0.052^{* * *} \\
(0.01)\end{array}$ \\
\hline Peer effects & $\begin{array}{c}0.324^{* * *} \\
(0.07)\end{array}$ & $\begin{array}{c}0.145^{* * *} \\
(0.04)\end{array}$ & $\begin{array}{c}0.355^{* * *} \\
(0.07)\end{array}$ & $\begin{array}{c}0.131^{* * *} \\
(0.04)\end{array}$ \\
\hline \multicolumn{5}{|l|}{ Random-effects } \\
\hline Country level (estimate/se) & $\begin{array}{c}0.000 \\
(0.619)\end{array}$ & $\begin{array}{c}0.000 \\
(0.000)\end{array}$ & $\begin{array}{c}0.000 \\
(0.565)\end{array}$ & $\begin{array}{c}0.000 \\
(0.000)\end{array}$ \\
\hline City level (estimate/se) & $\begin{array}{c}0.796 \\
(0.171)\end{array}$ & $\begin{array}{c}0.964 \\
(0.180)\end{array}$ & $\begin{array}{c}0.772 \\
(0.174)\end{array}$ & $\begin{array}{c}0.966 \\
(0.181)\end{array}$ \\
\hline$N$ & 3,225 & 3,225 & 2,950 & 2,950 \\
\hline$F-$ Statistic & $41.22^{* * *}$ & $59.23^{* * *}$ & $38.91^{* * *}$ & $70.61^{* * *}$ \\
\hline
\end{tabular}

justifiable. This finding is quite consistent with the findings in our list experiment. In other words, individuals who rely on private health insurance, and who are independent of the main state provided public goods, are less compelled to pay taxes because they are less reliant on state-provided services, and they perceive that the reciprocal benefit derived from the tax contract is lower.

Similar to our findings from our list experiment (see Figure 1), this effect is insensitive to changes in income. We estimated a model including the multiplicative interaction between employer-sponsored, private insurance and reported income (see Table A.8 in the Appendix) and find that the level of reported income does not affect tax morale among those with private insurance.

Also, consistent with our findings in the list experiment, the estimates for peer effects 
are positive and statistically significant across all models. This indicates that individuals are more willing to evade taxes if they perceive that their peers are complying obediently. This suggests that higher perceived levels of peer compliance triggers free-riding incentives among the respondents. Like in the list experiment, this evidence indicates that "voluntary compliance' (or 'voluntary cooperation') is inherently fragile in Latin America because individuals behave like income-maximizing free riders, and when they observe that others are contributing, they try to minimize their contributions to public finances (Fischbacher and Gachter, 2010).

We also find evidence that opting out is contingent on state capacity. In Table A.7 in the Appendix, we estimate the joint effect of opting out together with different indicators of state capacity. Once again, these models show that private health insurance has a positive and significant effect on the willingness to evade taxes; but they also show that, at higher levels of state capacity, individuals with private insurance are less likely to opt out relative to those with private health insurance in states with lower levels of state capacity. In other words, increasing levels of state capacity attenuate the effect of opting out on tax morale.

Finally, the results presented in Table 4 suggest that tax morale is lower among individuals who perceive that inequality is a serious problem and those who have strong preferences for redistribution. This demonstrates that attitudes towards redistribution and preferences for redistribution matter for tax compliance; consequently, more progressive tax schedules could boost tax morale. The results presented in Table A.8 also show that the effect of private health insurance is insensitive to changes in preferences for redistribution. 


\section{Concluding remarks}

At the heart of the social contract is an agreement that the state will provide for its citizens through public goods and that citizens will contribute what they can to help the state to function. However, in many countries, this reciprocal contract appears to be fractured. What determines tax morale in low-capacity states, where public goods are often considered inadequate and where norms of tax compliance are low? We argue that, in such contexts, many individuals opt out of the social contract. That is, they prefer to substitute stateprovided goods for private providers, rather than pay for public goods through taxes or free-ride to receive those goods. Specifically, citizens are unlikely to pay taxes if they have

private health insurance. For this group, their perception of the reciprocal benefit that they will receive from paying taxes will be lower as they opt for a non tax-funded health system. Consequently, the willingness of this group to evade taxes will be higher relative to other Latin American citizens.

We test this argument through an analysis of an original survey experiment in Mexico City. Mexico, with its notoriously low tax compliance and weak conditions for tax morale, is an ideal context to study this question. The methodological challenge in answering this question is measuring tax morale in an unbiased way, given that individuals have several incentives to lie or misrepresent their willingness to pay taxes. It is highly plausible that they would under-report their willingness to illegally evade taxes and over-report their willingness to pay taxes that help the poor. Therefore, we conducted a survey that included a list experiment to measure tax morale and alleviate concerns of social desirability bias.

We find that tax morale is, in fact, quite low. Willingness to evade taxes is high - around 17\%. Controlling for key variables, we find that evasion increases among individuals who have bought themselves independence from the welfare state. And when we examine this contention with a larger cross-national dataset, the results are very similar. More traditional expectations of reciprocity do not significantly impact the willingness to evade taxes. Upon closer examination, we find that those individuals at the very highest and very lowest ranges 
of socio-economic status choose, or are forced, to substitute state-provided health care for private providers. Across this economic stratum, those who choose not to opt out are unlikely to evade taxes. We contend that opting out is a product of preferences about public-goods, and not of social class or demographic self-interest.

Therefore, in order to mend the social contract at the level of the citizen, it is important to mend the social contract at the level of the state. Citizens need to perceive that stateprovided goods are worth their while, relative to private providers, in order to contribute to the tax system. In Latin America, where the quality and efficiency of state-provided public goods varies widely both between and within countries, then this is a real problem. Governments need to provide public goods fairly and efficiently and these goods must be perceived as being at least of comparable quality to equivalent private services. Only then will tax morale across Latin America improve. 


\section{References}

Ahlquist, J. S. (2014). Item count technique estimators under respondent error. In meetings of the Midwest Political Science Association.(CRAN). URL: http://CRAN. R-project. org/package= list.

Ahlquist, J. S. (2018). List experiment design, non-strategic respondent error, and item count technique estimators. Political Analysis, 26(1):34-53.

Alcaraz, C., Chiquiar, D., and Salcedo, A. (2015). Informality and segmentation in the Mexican labor market. Technical report, Working Papers, Banco de México.

Allingham, M. G. and Sandmo, A. (1972). Income tax evasion: A theoretical analysis. Journal of public economics, 1(3-4):323-338.

Ardanaz, M. and Scartascini, C. (2013). Inequality and Personal Income Taxation: The Origins and Effects of Legislative Malapportionment. Comparative Political Studies, 46(12):1636-1663.

Ballard-Rosa, C., Martin, L., and Scheve, K. (2017). The structure of American income tax policy preferences. The Journal of Politics, 79(1).

Beramendi, P. and Rehm, P. (2016). Who gives, who gains? Progressivity and Preferences. Comparative Political Studies, 49(4):529-563.

Bergman, M. (2010). Tax evasion and the rule of law in Latin America: The political culture of cheating and compliance in Argentina and Chile. Penn State Press.

Bird, R. M. and Zolt, E. M. (2015). Fiscal contracting in Latin America. World Development, $67: 323-335$.

Blair, G., Chou, W., and Imai, K. (2018). List experiments with measurement error. Technical report, Technical report. Princeton University. https://imai. princeton. edu ....

Blair, G. and Imai, K. (2012). Statistical analysis of list experiments. Political Analysis, pages $47-77$. 
Bodea, C. and LeBas, A. (2016). The origins of voluntary compliance: attitudes toward taxation in urban Nigeria. British Journal of Political Science, 46(1):215-238.

Bradburn, N. M., Sudman, S., Blair, E., and Stocking, C. (1978). Question threat and response bias. Public Opinion Quarterly, 42(2):221-234.

Brooks, S. (2009). Social Protection and the market in Latin America. Cambridge University Press.

CAF (2012). Public Finance for Development: Strengthening the connection between income and expenditure. Andean Development Corporation.

Carrillo, P., Castro, E., and Scartascini, C. (2017). Do rewards work?: Evidence from the randomization of public works. IDB Working Paper Series, (794).

Castañeda, N. and Doyle, D. (2019). Progressive tax policy and informal labor in developing economies. $0(0)$.

Castañeda, N. (2017). Business coordination and tax politics. Political Studies, 65(1):122-143.

Castro, L. and Scartascini, C. (2015). Tax compliance and enforcement in the Pampas evidence from a field experiment. Journal of Economic Behavior \& Organization, 116:65-82.

Centeno, M. A. (1997). Blood and debt: War and taxation in nineteenth-century Latin America. American Journal of sociology, 102(6):1565-1605.

Cotlear, D., Gómez-Dantés, O., Knaul, F., Atun, R., Barreto, I. C., Cetrángolo, O., Cueto, M., Francke, P., Frenz, P., Guerrero, R., et al. (2015). Overcoming social segregation in health care in latin america. The Lancet, 385(9974):1248-1259.

Cowell, F. A. and Gordon, J. P. (1988). Unwillingness to pay: Tax evasion and public good provision. Journal of Public Economics, 36(3):305-321.

Cullen, J. B., Turner, N., and Washington, E. L. (2018). Political Alignment, Attitudes Toward Government and Tax Evasion. Technical Report 24323, National Bureau of Economic Research. 
Daude, C., Gutierrez, H., Melguizo, A., et al. (2013). What drives tax morale? A focus on emerging economies. Review of Public Economics, 207(4):9-40.

De Jonge, C. P. K. and Nickerson, D. W. (2014). Artificial inflation or deflation? assessing the item count technique in comparative surveys. Political Behavior, 36(3):659-682.

Del Carpio, L. (2014). Are the Neighbors Cheating?: Evidence from a Social Norm Experiment on Property Taxes in Peru.

Doerrenberg, P. and Peichl, A. (2013). Progressive taxation and tax morale. Public Choice, 155(3-4):293-316.

Duch, R. M. and Solaz, H. (2015). Why we cheat: Experimental evidence on tax compliance.

Dwenger, N., Kleven, H., Rasul, I., and Rincke, J. (2016). Extrinsic and intrinsic motivations for tax compliance: Evidence from a field experiment in Germany. American Economic Journal: Economic Policy, 8(3):203-232.

ECLAC (2017). Fiscal Panorama of Latin America and the Caribbean 2017: Mobilizing resources to finance sustainable development. ECLAC.

Fairfield, T. (2015). Private Wealth and Public Revenue in Latin America: Business Power and Tax Politics. Cambridge University Press.

Fehr, E. and Gächter, S. (2000). Fairness and retaliation: The economics of reciprocity. Journal of economic perspectives, 14(3):159-181.

Fergusson, L., Molina, C., and Riano, J. F. (2017). I evade taxes, and so what? A new database and evidence from Colombia. Technical Report 21.

Ferreira, F. H., Messina, J., Rigolini, J., López-Calva, L.-F., Lugo, M. A., Vakis, R., Ló, L. F., et al. (2012). Economic mobility and the rise of the Latin American middle class. World Bank Publications.

Fischbacher, U. and Gachter, S. (2010). Social preferences, beliefs, and the dynamics of free riding in public goods experiments. American Economic Review, 100(1):541-56. 
Flores-Macias, G. and Sánchez-Talanquer, M. (2019). Building the modern state in developing countries: Understanding the relationship between public safety and taxes with evidence from mexico.

Flores-Macías, G. A. (2014). Financing security through elite taxation: The case of colombia's "democratic security taxes". Studies in Comparative International Development, 49(4):477-500.

Flores-Macías, G. A. (2018). Building support for taxation in developing countries: Experimental evidence from mexico. World Development, 105:13-24.

Frey, B. S. and Torgler, B. (2007). Tax morale and conditional cooperation. Journal of Comparative Economics, 35(1):136-159.

Fuentes Castro, H. J., Zamudio Carrillo, A., Barajas, S., Ayllon, G., Mora Rivera, J., and Serrano Diez, M. E. (2013). Estudio de evasión global de impuestos. Technical report.

Glynn, A. N. (2013). What can we learn with statistical truth serum? design and analysis of the list experiment. Public Opinion Quarterly, 77(S1):159-172.

Gómez Sabaini, J. C. and Jiménez, J. P. (2012). Tax structure and tax evasion in Latin America. ECLAC.

Hart, A. (2010). Death of the Partisan? Globalization and Taxation in South America, 1990-2006. Comparative Political Studies, 43(3):304-328.

Imai, K. (2011). Multivariate regression analysis for the item count technique. Journal of the American Statistical Association, 106(494):407-416.

INEGI (2010). Censo de población y vivienda 2010.

INEGI (2015). Encuesta intercensal 2015.

Kiewiet de Jonge, C. and Nickerson, D. (2014). Artificial inflation or deflation? Assessing the item count technique in comparative surveys. Political Behavior, 36(3):659-682. 
Kurtz, M. J. (2013). Latin American state building in comparative perspective: Social foundations of institutional order. Cambridge University Press.

Kuziemko, I., Norton, M. I., Saez, E., and Stantcheva, S. (2015). How elastic are preferences for redistribution? evidence from randomized survey experiments. The American Economic Review, 105(4):1478-1508.

Levi, M. (1989). Of rule and revenue, volume 13. Univ of California Press.

Luttmer, E. and Singhal, M. (2014). Tax morale. Journal of Economic Perspectives, 28(4):149-168.

Martin, L. (2014). Taxation, loss aversion, and accountability: theory and experimental evidence for taxation's effect on citizen behavior. Technical report.

McGuire, J. W. (2014). Causes, characteristics, and consequences? Routledge Handbook of Latin American politics, page 200.

O'Donnell, G. (1993). On the state, democratization and some conceptual problems: A Latin American view with glances at some post-communist countries. World Development, 21(8):13551369.

OECD (2016). OECD Reviews of Health Systems: Mexico 2016.

OECD (2019). Revenue Statistics in Latin America and the Caribbean 2019. OECD.

Ortega, D., Ronconi, L., and Sanguinetti, P. (2016). Reciprocity and willingness to pay taxes: Evidence from a survey experiment in Latin America. Economía, 16(2):55-87.

Paler, L. (2013). Keeping the public purse: An experiment in windfalls, taxes, and the incentives to restrain government. American Political Science Review, 107(04):706-725.

Romero, V., Paras, P., and Zechmeister, E. (2015). Cultura política de la democracia en Mexico y en las Américas, 2014: Gobernabilidad democrática a través de 10 años del Barómetro de las Américas. ITAM. 
Rosenfeld, B., Imai, K., and Shapiro, J. N. (2016). An empirical validation study of popular survey methodologies for sensitive questions. American Journal of Political Science, 60(3):783-802.

Rousseau, J.-J. (1920). The Social Contract: \& Discourses. Number 660. JM Dent \& Sons.

Rueda, D. and Stegmueller, D. (2016). The externalities of inequality: Fear of crime and preferences for redistribution in western europe. American Journal of Political Science, 60(2):472-489.

SAT (2013). Conductas en el cumplimiento y evasión. Technical report.

Scheve, K. and Stasavage, D. (2016). Taxing the rich: A history of fiscal fairness in the United States and Europe. Princeton University Press.

Schneider, B. R. (2013). Hierarchical Capitalism in Latin America. Cambridge University Press.

Segura-Ubiergo, A. (2007). The political economy of the welfare state in Latin America: globalization, democracy, and development. Cambridge University Press.

Slemrod, J. (2018). Tax compliance and enforcement. NBER Working Paper Series, (24799).

Soifer, H. D. (2015). State Building in Latin America. Cambridge University Press.

Tilly, C. (1992). Coercion, capital, and European states, AD 990-1992. Blackwell Oxford.

Torgler, B. (2005). Tax morale in Latin America. Public Choice, 122(1-2):133-157.

Wibbels, E. and Ahlquist, J. S. (2011). Development, trade, and social insurance. International Studies Quarterly, 55(1):125-149.

Wibbels, E. and Arce, M. (2003). Globalization, taxation, and burden-shifting in Latin America. International Organization, 57(01):111-136. 


\section{Appendix}

\section{Balance Tests}

Table A.1: Balance Across Treatment and Control Groups: Variables in Model

\begin{tabular}{|c|c|c|c|c|}
\hline Measure & Categories & Treated & Control & $\chi^{2}$ Test \\
\hline $\mathrm{N}$ & & 550 & 550 & NA \\
\hline$\%$ Male & & $49.82 \%$ & $46.91 \%$ & $\begin{array}{l}\chi^{2}=0.82 \\
\text { p-value }=0.4 \\
\text { p-val }\end{array}$ \\
\hline SES (AMAI) & $\begin{array}{l}\mathrm{ABC}+ \\
\mathrm{C} \\
\mathrm{D}+ \\
\mathrm{D} / \mathrm{E}\end{array}$ & $\begin{array}{l}19.88 \% \\
31.38 \% \\
20.86 \% \\
27.88 \%\end{array}$ & $\begin{array}{l}23.86 \% \\
29.36 \% \\
17.80 \% \\
28.98 \%\end{array}$ & $\begin{array}{l}\chi^{2}=3.6 \\
\mathrm{df}=3 \\
\mathrm{p} \text {-value }=0.3\end{array}$ \\
\hline Education & $\begin{array}{l}\text { None to Primary } \\
\text { Preparatory } \\
\text { Secondary } \\
\text { Technical } \\
\text { University + }\end{array}$ & $\begin{array}{l}4.55 \% \\
35.64 \% \\
28.55 \% \\
14.73 \% \\
16.55 \%\end{array}$ & $\begin{array}{l}4.75 \% \\
35.04 \% \\
24.45 \% \\
14.96 \% \\
20.80 \%\end{array}$ & $\begin{array}{l}\chi^{2}=4.5 \\
\mathrm{df}=4 \\
\mathrm{p} \text {-value }=0.3\end{array}$ \\
\hline \% Employed & & $60 \%$ & $57.27 \%$ & $\begin{array}{l}\chi^{2}=0.73 \\
\text { df }=1, \\
\text {-value }=0.4\end{array}$ \\
\hline \% Private Health Insurance & & $29.76 \%$ & $33.02 \%$ & $\begin{array}{l}\chi_{\mathrm{df}}^{2}=1.2 \\
\mathrm{p} \text {-value }=0.3\end{array}$ \\
\hline
\end{tabular}


Table A.2: Balance Across Treatment and Control Groups: Types of Employment

\begin{tabular}{|c|c|c|c|}
\hline Measure & Treated & Control & $\chi^{2}$ Test \\
\hline \% Employed currently & $51.64 \%$ & $48.91 \%$ & $\begin{array}{l}\chi^{2}=0.71 \\
\mathrm{df}=1 \\
\mathrm{p} \text {-value }=0.4\end{array}$ \\
\hline \% Seasonally employed & $8.55 \%$ & $8.73 \%$ & $\begin{array}{l}\chi^{2}=0 \\
\text { df }=1 \\
p \text {-value }=1\end{array}$ \\
\hline$\%$ Looking for work & $2.73 \%$ & $3.46 \%$ & $\begin{array}{l}\chi^{2}=0.27 \\
\mathrm{df}=1 \\
\mathrm{p} \text {-value }=0.6\end{array}$ \\
\hline$\%$ Student & $13.45 \%$ & $12.18 \%$ & $\begin{array}{l}\chi^{2}=0.29 \\
\text { df }=1 \\
\text { p-value }=0.6\end{array}$ \\
\hline \% Homemaker & $27.82 \%$ & $33.09 \%$ & $\begin{array}{l}\chi_{\mathrm{f}}^{2}=3.4 \\
\mathrm{~d}=1 \\
\mathrm{p} \text {-value }=0.07\end{array}$ \\
\hline$\%$ Retired & $3.27 \%$ & $4.73 \%$ & $\begin{array}{l}\chi^{2}=1.2 \\
\mathrm{df}=1 \\
\mathrm{p} \text {-value }=0.3\end{array}$ \\
\hline$\%$ Not looking for work & $2.36 \%$ & $1.46 \%$ & $\begin{array}{l}\chi^{2}=0.78 \\
\mathrm{df}=1 \\
\mathrm{p} \text {-value }=0.4\end{array}$ \\
\hline
\end{tabular}




\section{List Experiments: Full Output}

Table A.3: Multivariate Analysis of Tax Evasion List Experiment, Linear Estimates

\begin{tabular}{|c|c|c|c|c|c|c|}
\hline & $\begin{array}{l}(1) \\
b /(s e)\end{array}$ & $\begin{array}{l}(2) \\
b /(s e)\end{array}$ & $\begin{array}{c}(3) \\
b /(s e)\end{array}$ & $\begin{array}{l}(4) \\
b /(s e)\end{array}$ & $\begin{array}{l}(5) \\
b /(s e)\end{array}$ & $\begin{array}{l}(6) \\
b /(s e)\end{array}$ \\
\hline \multicolumn{7}{|c|}{ Difference in mean numbers of items between treatment and control lists: } \\
\hline Treatment dummy & $\begin{array}{l}0.110 \\
(0.209)\end{array}$ & $\begin{array}{c}0.039 \\
(0.308)\end{array}$ & $\begin{array}{c}0.021 \\
(0.312)\end{array}$ & $\begin{array}{c}-0.084 \\
(0.281)\end{array}$ & $\begin{array}{c}0.032 \\
(0.260)\end{array}$ & $\begin{array}{c}-0.209 \\
(0.468)\end{array}$ \\
\hline Treat*Private healthcare & $\begin{array}{l}0.257^{* * *} \\
(0.089)\end{array}$ & $\begin{array}{l}0.233^{* * *} \\
(0.090)\end{array}$ & $\begin{array}{l}0.296^{* * *} \\
(0.090)\end{array}$ & $\begin{array}{l}0.302^{* * *} \\
(0.092)\end{array}$ & $\begin{array}{l}0.194^{* *} \\
(0.092)\end{array}$ & $\begin{array}{l}0.223^{* *} \\
(0.095)\end{array}$ \\
\hline Treat*SES & $\begin{array}{c}0.002 \\
(0.040)\end{array}$ & $\begin{array}{r}-0.003 \\
(0.040)\end{array}$ & $\begin{array}{c}0.028 \\
(0.040)\end{array}$ & $\begin{array}{c}0.006 \\
(0.042)\end{array}$ & $\begin{array}{c}-0.013 \\
(0.041)\end{array}$ & $\begin{array}{l}0.014 \\
(0.043)\end{array}$ \\
\hline Treat*Education & $\begin{array}{l}0.004 \\
(0.019)\end{array}$ & $\begin{array}{l}0.004 \\
(0.019)\end{array}$ & $\begin{array}{l}0.005 \\
(0.019)\end{array}$ & $\begin{array}{l}0.002 \\
(0.019)\end{array}$ & $\begin{array}{c}-0.006 \\
(0.019)\end{array}$ & $\begin{array}{r}-0.007 \\
(0.021)\end{array}$ \\
\hline Treat*Employed & $\begin{array}{c}-0.029 \\
(0.081)\end{array}$ & $\begin{array}{r}-0.027 \\
(0.082)\end{array}$ & $\begin{array}{r}-0.078 \\
(0.082)\end{array}$ & $\begin{array}{r}-0.047 \\
(0.085)\end{array}$ & $\begin{array}{r}0.0003 \\
(0.085)\end{array}$ & $\begin{array}{c}-0.065 \\
(0.090)\end{array}$ \\
\hline Treat*Govt. helps poor & & $\begin{array}{c}0.008 \\
(0.021)\end{array}$ & & & & $\begin{array}{r}-0.004 \\
(0.024)\end{array}$ \\
\hline Treat*Perceived corruption & & $\begin{array}{l}0.008 \\
(0.024)\end{array}$ & & & & $\begin{array}{r}-0.018 \\
(0.027)\end{array}$ \\
\hline Treat*Inequality & & & $\begin{array}{l}-0.015 \\
(0.051)\end{array}$ & & & $\begin{array}{r}-0.035 \\
(0.057)\end{array}$ \\
\hline Treat*Success=family status & & & $\begin{array}{r}-0.054 \\
(0.052)\end{array}$ & & & $\begin{array}{r}-0.043 \\
(0.058)\end{array}$ \\
\hline Treat*Success $=$ hard work & & & $\begin{array}{c}0.071 \\
(0.047)\end{array}$ & & & $\begin{array}{l}0.061 \\
(0.051)\end{array}$ \\
\hline Treat*Audit risk & & & & $\begin{array}{c}0.025 \\
(0.016)\end{array}$ & & $\begin{array}{l}0.020 \\
(0.018)\end{array}$ \\
\hline Treat*Sanction level & & & & $\begin{array}{c}0.016 \\
(0.052)\end{array}$ & & $\begin{array}{c}0.039 \\
(0.056)\end{array}$ \\
\hline Treat*Peer effects & & & & & $\begin{array}{c}0.071 \\
(0.049)\end{array}$ & $\begin{array}{l}0.126^{* *} \\
(0.053)\end{array}$ \\
\hline \multicolumn{7}{|c|}{ Mean number of items in control list } \\
\hline Private healthcare & $\begin{array}{l}-0.030 \\
(0.061)\end{array}$ & $\begin{array}{l}-0.008 \\
(0.063)\end{array}$ & $\begin{array}{l}-0.028 \\
(0.062)\end{array}$ & $\begin{array}{l}-0.038 \\
(0.063)\end{array}$ & $\begin{array}{l}-0.004 \\
(0.063)\end{array}$ & $\begin{array}{c}0.011 \\
(0.066)\end{array}$ \\
\hline SES & $\begin{array}{l}0.036 \\
(0.028)\end{array}$ & $\begin{array}{l}0.041 \\
(0.028)\end{array}$ & $\begin{array}{c}0.041 \\
(0.028)\end{array}$ & $\begin{array}{l}0.045 \\
(0.028)\end{array}$ & $\begin{array}{c}0.043 \\
(0.029)\end{array}$ & $\begin{array}{l}0.064^{* *} \\
(0.030)\end{array}$ \\
\hline Education & $\begin{array}{c}0.016 \\
(0.013)\end{array}$ & $\begin{array}{c}0.016 \\
(0.014)\end{array}$ & $\begin{array}{c}0.016 \\
(0.014)\end{array}$ & $\begin{array}{c}0.014 \\
(0.014)\end{array}$ & $\begin{array}{c}0.017 \\
(0.014)\end{array}$ & $\begin{array}{c}0.012 \\
(0.015)\end{array}$ \\
\hline Employed & $\begin{array}{c}0.003 \\
(0.057)\end{array}$ & $\begin{array}{r}-0.016 \\
(0.058)\end{array}$ & $\begin{array}{c}0.024 \\
(0.057)\end{array}$ & $\begin{array}{c}0.007 \\
(0.058)\end{array}$ & $\begin{array}{c}-0.032 \\
(0.059)\end{array}$ & $\begin{array}{r}-0.013 \\
(0.062)\end{array}$ \\
\hline Govt. helps the poor & & $\begin{array}{c}-0.001 \\
(0.015)\end{array}$ & & & & $\begin{array}{l}0.007 \\
(0.016)\end{array}$ \\
\hline Perceived corruption & & $\begin{array}{l}-0.040^{* *} \\
(0.017)\end{array}$ & & & & $\begin{array}{c}-0.037^{* *} \\
(0.018)\end{array}$ \\
\hline Inequality gap & & & $\begin{array}{l}0.097^{* * *} \\
(0.035)\end{array}$ & & & $\begin{array}{l}0.090^{* *} \\
(0.039)\end{array}$ \\
\hline Success $=$ family status & & & $\begin{array}{l}-0.007 \\
(0.036)\end{array}$ & & & $\begin{array}{r}-0.003 \\
(0.040)\end{array}$ \\
\hline Success $=$ hard work & & & $\begin{array}{l}0.038 \\
(0.033)\end{array}$ & & & $\begin{array}{l}0.041 \\
(0.035)\end{array}$ \\
\hline Audit risk & & & & 0.010 & & 0.014 \\
\hline Sanction level & & & & $\begin{array}{l}(0.011) \\
0.067^{*} \\
(0.037)\end{array}$ & & $\begin{array}{c}(0.012) \\
0.047 \\
(0.039)\end{array}$ \\
\hline Peer effects & & & & & $\begin{array}{c}0.009 \\
(0.035)\end{array}$ & $\begin{array}{c}-0.003 \\
(0.037)\end{array}$ \\
\hline Constant & $\begin{array}{l}1.048^{* * *} \\
(0.150)\end{array}$ & $\begin{array}{l}1.375^{* * *} \\
(0.217)\end{array}$ & $\begin{array}{l}0.598^{* * *} \\
(0.219)\end{array}$ & $\begin{array}{l}0.787^{* * *} \\
(0.201)\end{array}$ & $\begin{array}{l}1.008^{* * *} \\
(0.187)\end{array}$ & $\begin{array}{l}0.665^{* *} \\
(0.324)\end{array}$ \\
\hline Observations & 1,004 & 988 & 928 & 909 & 923 & 775 \\
\hline $\mathrm{R}^{2}$ & 0.042 & 0.053 & 0.078 & 0.074 & 0.051 & 0.126 \\
\hline
\end{tabular}

Note: Significance levels: ${ }^{*} \mathrm{p}<0.1 ;{ }^{* *} \mathrm{p}<0.05 ;{ }^{* * *} \mathrm{p}<0.01$ 


\section{Alternative specifications of list experiment}

In this section, we turn to alternative specifications of the multivariate analysis of the list experiment. The traditional way to analyze list experiments is a simple difference in means, in which the number of items is estimated as a linear function of treatment assignment. In order to conduct multivariate analysis, covariates are interacted with treatment assignment, allowing us to see the proportion of respondents selecting the sensitive item for a discrete change in the independent variable.

The difference-in-means estimator is the most traditional approach, but recent advancements to list experiment analysis have leveraged additional information available in the list experiment response distribution to conduct multivariate analysis. The maximum likelihood estimator (MLreg) is the most efficient of these new techniques, relying on responses at the extreme values ( 0 and the maximum number of items) of the response distribution, assuming that these data represent truthful responses, and modeling support for the sensitive item as partially missing data. Given the noise traditionally found around list experiment estimates, the more efficient MLreg is an attractive alternative to the difference-in-means estimator.

Unfortunately, we are unable to analyze our data using MLreg, as the procedure is computationally unstable for our list experiment. This is not entirely surprising, given recent research on MLreg (see Ahlquist, 2014, 2018; Blair et al., 2018). Ahlquist (2014, 2018) examines the estimator's sensitivity to various forms of non-strategic error and finds that the estimator's computational stability is quite fragile, especially when compared to the difference-in-means estimator.

We believe that the estimator fails to compute because of the relatively high number of respondents who selected 0 items ( $\sim 4 \%$ in each group). This might be indicative of "bottom bias" (Ahlquist 2016), a type of non-strategic measurement error in which respondents provide a response of 0 rather than providing the number of items they would consider. While it is possible that respondents would not be willing to consider any of the baseline items to save money, we find it unlikely that they would even not be willing to consider spending 
less money on groceries. An alternative explanation is that respondents simply stated that their answer was 0 without engaging in the question. In this case, respondents are not lying in order to conceal their support for the sensitive item; they are simply satisficing. In this case, Ahlquist (2014)'s Monte Carlo experiments suggest that a list experiment such as ours (with a medium prevalence sensitive item and some degree of "bottom-biased" non-strategic error) would result not be computationally stable between $10 \%-15 \%$ of the time. The most recent version of MLreg includes new estimators that are robust to non-strategic measurement error, but they only address "uniform" or "top-biased" error, not "bottom-biased" error.

Nevertheless, Imai developed an alternative estimator, the non-linear least squares estimator (NLSreg), which makes fewer distributional assumptions than MLreg. Consequently, it is more robust than MLreg, but less efficient, and is the recommended technique to use in instances of non-strategic measurement error (Blair et al., 2018). Our results, presented in Table A.4, indicate that the NLS estimates are comparable to the OLS estimates in terms of sign and significance. 
Table A.4: Multivariate Analysis of List Experiment

\begin{tabular}{|c|c|c|}
\hline & $\begin{array}{l}\text { OLS } \\
b /(s e)\end{array}$ & $\begin{array}{l}\text { NLS } \\
b /(s e)\end{array}$ \\
\hline \multicolumn{3}{|c|}{ Sensitive Item (Difference between treatment and control lists) } \\
\hline Private healthcare & $\begin{array}{l}0.223^{* *} \\
(0.102)\end{array}$ & $\begin{array}{l}1.380^{* *} \\
(0.617)\end{array}$ \\
\hline SES & $\begin{array}{c}0.014 \\
(0.044)\end{array}$ & $\begin{array}{c}0.015 \\
(0.278)\end{array}$ \\
\hline Education & $\begin{array}{c}-0.007 \\
(0.020)\end{array}$ & $\begin{array}{c}-0.104 \\
(0.126)\end{array}$ \\
\hline Employed & $\begin{array}{c}-0.065 \\
(0.093)\end{array}$ & $\begin{array}{c}-0.674 \\
(0.584)\end{array}$ \\
\hline Govt. helps poor & $\begin{array}{c}-0.004 \\
(0.024)\end{array}$ & $\begin{array}{c}-0.036 \\
(0.153)\end{array}$ \\
\hline Perceived corruption & $\begin{array}{c}-0.018 \\
(0.026)\end{array}$ & $\begin{array}{c}-0.125 \\
(0.167)\end{array}$ \\
\hline Inequality & $\begin{array}{c}-0.035 \\
(0.058)\end{array}$ & $\begin{array}{c}-0.352 \\
(0.352)\end{array}$ \\
\hline Success $=$ family status & $\begin{array}{c}-0.043 \\
(0.061)\end{array}$ & $\begin{array}{c}-0.111 \\
(0.365)\end{array}$ \\
\hline Success $=$ hard work & $\begin{array}{c}0.061 \\
(0.055)\end{array}$ & $\begin{array}{c}0.487 \\
(0.363)\end{array}$ \\
\hline Audit risk & $\begin{array}{c}0.020 \\
(0.020)\end{array}$ & $\begin{array}{c}0.191 \\
(0.118)\end{array}$ \\
\hline Sanction level & $\begin{array}{c}0.039 \\
(0.058)\end{array}$ & $\begin{array}{c}0.130 \\
(0.354)\end{array}$ \\
\hline Peer effects & $\begin{array}{l}0.126^{* *} \\
(0.058)\end{array}$ & $\begin{array}{l}0.945^{* *} \\
(0.440)\end{array}$ \\
\hline Constant & $\begin{array}{c}-0.209 \\
(0.470) \\
\end{array}$ & $\begin{array}{c}-4.265 \\
(3.005) \\
\end{array}$ \\
\hline \multicolumn{3}{|c|}{ Control list } \\
\hline Private healthcare & $\begin{array}{c}0.011 \\
(0.061)\end{array}$ & $\begin{array}{c}0.015 \\
(0.082)\end{array}$ \\
\hline SES & $\begin{array}{l}0.064^{* *} \\
(0.028)\end{array}$ & $\begin{array}{l}0.089^{* *} \\
(0.037)\end{array}$ \\
\hline Education & $\begin{array}{c}0.012 \\
(0.013)\end{array}$ & $\begin{array}{c}0.018 \\
(0.018)\end{array}$ \\
\hline Employed & $\begin{array}{c}-0.013 \\
(0.055)\end{array}$ & $\begin{array}{c}-0.018 \\
(0.073)\end{array}$ \\
\hline Govt. helps poor & $\begin{array}{c}0.007 \\
(0.014)\end{array}$ & $\begin{array}{c}0.010 \\
(0.019)\end{array}$ \\
\hline Perceived corruption & $\begin{array}{c}-0.037^{* *} \\
(0.016)\end{array}$ & $\begin{array}{c}-0.051^{* *} \\
(0.021)\end{array}$ \\
\hline Inequality & $\begin{array}{l}0.090^{* *} \\
(0.037)\end{array}$ & $\begin{array}{l}0.125^{* *} \\
(0.049)\end{array}$ \\
\hline Success $=$ family status & $\begin{array}{c}-0.003 \\
(0.035)\end{array}$ & $\begin{array}{c}-0.002 \\
(0.046)\end{array}$ \\
\hline Success $=$ hard work & $\begin{array}{c}0.041 \\
(0.034)\end{array}$ & $\begin{array}{c}0.057 \\
(0.046)\end{array}$ \\
\hline Audit risk & $\begin{array}{c}0.014 \\
(0.012)\end{array}$ & $\begin{array}{c}0.019 \\
(0.015)\end{array}$ \\
\hline Sanction level & $\begin{array}{c}0.047 \\
(0.036)\end{array}$ & $\begin{array}{c}0.066 \\
(0.048)\end{array}$ \\
\hline Peer effects & $\begin{array}{c}-0.003 \\
(0.035)\end{array}$ & $\begin{array}{c}-0.007 \\
(0.046)\end{array}$ \\
\hline Constant & $\begin{array}{l}0.665^{* *} \\
(0.281)\end{array}$ & $\begin{array}{c}-1.160^{* * *} \\
(0.378)\end{array}$ \\
\hline
\end{tabular}

Note: Significance levels: ${ }^{*} \mathrm{p}<0.1 ;{ }^{* *} \mathrm{p}<0.05 ;{ }^{* * *} \mathrm{p}<0.01$ 
In order to compare effect sizes across the OLS and NLS estimators, we compute predicted probabilities for each. In Figure A.1, we present the predicted probability of supporting tax evasion for those with private insurance (left panel) and without private insurance (right panel). Figure A.1 demonstrates that both groups of respondents would be willing to evade taxes, but that willingness increases (by roughly $22 \%$ points, as indicated in Table A.4 and Table 3 in the main body) among those with private insurance. In comparing the two estimators, it is clear that the willingness to evade taxes is highly comparable for the linear and non-linear least squares models, and the NLS estimator only has slightly smaller confidence intervals.

With Private Insurance

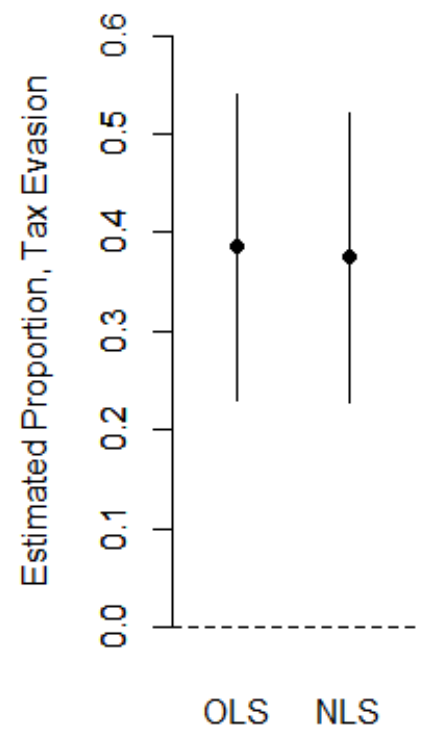

Without Private Insurance

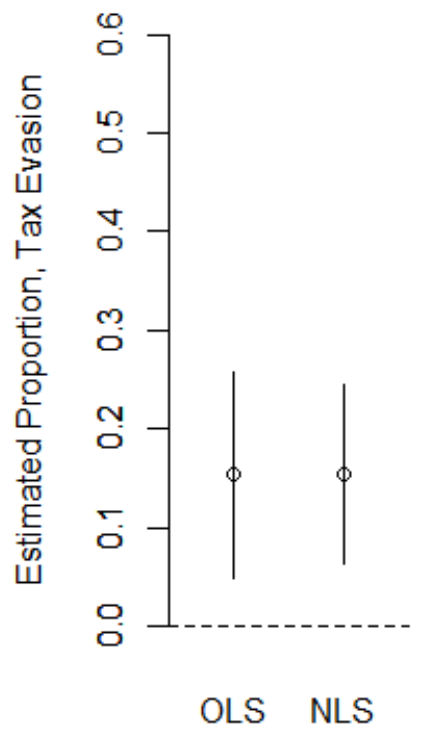

Figure A.1: Predicted probabilities of the willingness to evade taxes: Comparing OLS and NLS estimations 


\section{Alternative Specifications and Measures}

Table A.5: Private Health Insurance and Attitudes towards Tax Evasion, Country FixedEffects Specifications

\begin{tabular}{|c|c|c|c|c|}
\hline & $\begin{array}{c}\text { (1) } \\
\text { Country FE logit } \\
\text { b/se }\end{array}$ & $\begin{array}{c}(2) \\
\text { Country FE } \\
\text { b/se }\end{array}$ & $\begin{array}{c}\text { (3) } \\
\text { Country FE logit } \\
\text { b/se }\end{array}$ & $\begin{array}{c}\text { (4) } \\
\text { Country FE } \\
\text { b/se }\end{array}$ \\
\hline Private health insurance & $\begin{array}{c}0.504^{* *} \\
(0.23)\end{array}$ & $\begin{array}{l}0.107 \\
(0.17)\end{array}$ & & \\
\hline Independence from public goods & & & $\begin{array}{c}0.322^{* *} \\
(0.13)\end{array}$ & $\begin{array}{c}0.300^{* * *} \\
(0.09)\end{array}$ \\
\hline Household income & $\begin{array}{c}-0.000 \\
(0.00)\end{array}$ & $\begin{array}{l}-0.000 \\
(0.00)\end{array}$ & $\begin{array}{l}-0.000 \\
(0.00)\end{array}$ & $\begin{array}{r}-0.000 \\
(0.00)\end{array}$ \\
\hline Education & $\begin{array}{c}-0.044 \\
(0.03)\end{array}$ & $\begin{array}{c}-0.115^{* * *} \\
(0.02)\end{array}$ & $\begin{array}{c}-0.033 \\
(0.03)\end{array}$ & $\begin{array}{c}-0.100^{* * *} \\
(0.02)\end{array}$ \\
\hline ln the labor market & $\begin{array}{l}-0.937 \\
(1.15)\end{array}$ & $\begin{array}{r}-0.475 \\
(0.93)\end{array}$ & $\begin{array}{l}-0.967 \\
(1.18)\end{array}$ & $\begin{array}{l}0.057 \\
(1.01)\end{array}$ \\
\hline Strong preferences for redistribution & $\begin{array}{l}0.235^{*} \\
(0.12)\end{array}$ & $\begin{array}{l}0.067 \\
(0.08)\end{array}$ & $\begin{array}{l}0.206 \\
(0.13)\end{array}$ & $\begin{array}{l}0.006 \\
(0.08)\end{array}$ \\
\hline Perceived probability of sanction & $\begin{array}{l}0.005 \\
(0.02)\end{array}$ & $\begin{array}{c}-0.069^{* * *} \\
(0.01)\end{array}$ & $\begin{array}{l}-0.014 \\
(0.02)\end{array}$ & $\begin{array}{c}-0.078^{* * *} \\
(0.01)\end{array}$ \\
\hline Peer effects & $\begin{array}{c}0.360^{* * *} \\
(0.07)\end{array}$ & $\begin{array}{c}0.208^{* * *} \\
(0.04)\end{array}$ & $\begin{array}{c}0.390^{* * *} \\
(0.07)\end{array}$ & $\begin{array}{c}0.195^{* * *} \\
(0.04)\end{array}$ \\
\hline$N$ & 3,225 & 3,225 & 2,950 & 2,950 \\
\hline
\end{tabular}


Table A.6: Private Health Insurance and Attitudes towards Tax Evasion, City Fixed-Effects Specifications

\begin{tabular}{lcccc}
\hline \hline & $(1)$ & $(2)$ & $(3)$ & $(4)$ \\
& $\begin{array}{c}\text { City FE logit } \\
\mathrm{b} / \mathrm{se}\end{array}$ & $\begin{array}{c}\text { City FE } \\
\mathrm{b} / \mathrm{se}\end{array}$ & $\begin{array}{c}\text { City FE logit } \\
\mathrm{b} / \mathrm{se}\end{array}$ & $\begin{array}{c}\text { City FE } \\
\mathrm{b} / \mathrm{se}\end{array}$ \\
\hline \multirow{2}{*}{ Private health insurance } & & & & \\
& $0.514^{* *}$ & 0.067 & & \\
Independence from public goods & $(0.24)$ & $(0.16)$ & & \\
& & & $0.319^{* *}$ & $0.341^{* * *}$ \\
Household income & & & $(0.14)$ & $(0.09)$ \\
& -0.000 & -0.000 & -0.000 & -0.000 \\
Education & $(0.00)$ & $(0.00)$ & $(0.00)$ & $(0.00)$ \\
& -0.038 & $-0.101^{* * *}$ & -0.028 & $-0.082^{* * *}$ \\
ln the labor market & $(0.03)$ & $(0.02)$ & $(0.03)$ & $(0.02)$ \\
& -0.990 & -0.321 & -0.953 & 0.305 \\
Strong preferences for redistribution & $(1.17)$ & $(0.90)$ & $(1.20)$ & $(0.98)$ \\
& $0.301^{* *}$ & $0.150^{*}$ & $0.266^{* *}$ & 0.091 \\
Perceived probability of sanction & $(0.12)$ & $(0.08)$ & $(0.13)$ & $(0.08)$ \\
& 0.032 & $-0.044^{* * *}$ & 0.012 & $-0.050^{* * *}$ \\
Peer effects & $(0.02)$ & $(0.01)$ & $(0.02)$ & $(0.01)$ \\
& $0.312^{* * *}$ & $0.139^{* * *}$ & $0.339^{* * *}$ & $0.123^{* * *}$ \\
& $(0.07)$ & $(0.04)$ & $(0.07)$ & $(0.04)$ \\
\hline \hline
\end{tabular}

Note: Significance levels: ${ }^{*} p<0.10,{ }^{* *} p<0.05,{ }^{* * *} p<0.01$ 


\section{Private insurance, tax evasion, and state capacity}

Table A.7: Private Health Insurance, Attitudes towards Tax Evasion, and State Capacity. Latin America, 17 cities. Multi-level HLM Random Intercept Models

\begin{tabular}{|c|c|c|c|c|c|c|}
\hline & \multicolumn{6}{|c|}{ Dependent variable: tax evasion is justifiable } \\
\hline & $\begin{array}{c}(1) \\
b /(s e)\end{array}$ & $\begin{array}{c}(2) \\
b /(s e)\end{array}$ & $\begin{array}{c}(3) \\
b /(s e) \\
\end{array}$ & $\begin{array}{c}(4) \\
b /(s e)\end{array}$ & $\begin{array}{c}(5) \\
b /(s e)\end{array}$ & $\begin{array}{c}(6) \\
b /(s e)\end{array}$ \\
\hline Private health insurance & $\begin{array}{l}0.463^{*} \\
(0.24)\end{array}$ & $\begin{array}{l}6.602^{*} \\
(3.667)\end{array}$ & $\begin{array}{c}0.473^{* *} \\
(0.24)\end{array}$ & $\begin{array}{c}2.293^{* *} \\
(1.06)\end{array}$ & $\begin{array}{c}0.477^{* *} \\
(0.24)\end{array}$ & $\begin{array}{c}3.458^{* * *} \\
(0.99)\end{array}$ \\
\hline $\begin{array}{l}\text { State capacity indicators } \\
\text { Immunizations coverage (POL3) }\end{array}$ & $\begin{array}{l}0.031 \\
(0.03)\end{array}$ & $\begin{array}{l}0.038 \\
(0.03)\end{array}$ & & & & \\
\hline Private health*immunizations & & $\begin{array}{c}-0.068^{*} \\
(0.04)\end{array}$ & & & & \\
\hline Tax burden as \% GDP & & & $\begin{array}{l}0.011 \\
(0.03)\end{array}$ & $\begin{array}{l}0.018 \\
(0.03)\end{array}$ & & \\
\hline Private health*tax burden & & & & $\begin{array}{c}-0.069^{*} \\
(0.04)\end{array}$ & & \\
\hline Income taxation as \% GDP & & & & & $\begin{array}{l}0.043 \\
(0.12)\end{array}$ & $\begin{array}{l}0.073 \\
(0.12)\end{array}$ \\
\hline Private health*income taxation & & & & & & $\begin{array}{l}-0.499^{* * *} \\
\quad(0.17)\end{array}$ \\
\hline $\begin{array}{l}\text { Individual-level factors } \\
\text { Household income }\end{array}$ & $\begin{array}{l}-0.000 \\
(0.00)\end{array}$ & $\begin{array}{l}-0.000 \\
(0.00)\end{array}$ & $\begin{array}{r}-0.000 \\
(0.00)\end{array}$ & $\begin{array}{l}-0.000 \\
(0.00)\end{array}$ & $\begin{array}{r}-0.000 \\
(0.00)\end{array}$ & $\begin{array}{l}-0.000 \\
(0.00)\end{array}$ \\
\hline Education & $\begin{array}{r}-0.036 \\
(0.03)\end{array}$ & $\begin{array}{l}-0.037 \\
(0.03)\end{array}$ & $\begin{array}{l}-0.037 \\
(0.03)\end{array}$ & $\begin{array}{l}-0.038 \\
(0.03)\end{array}$ & $\begin{array}{l}-0.038 \\
(0.03)\end{array}$ & $\begin{array}{l}-0.038 \\
(0.03)\end{array}$ \\
\hline In the labor market & $\begin{array}{l}-0.934 \\
(1.17)\end{array}$ & $\begin{array}{l}-0.915 \\
(1.16)\end{array}$ & $\begin{array}{r}-0.943 \\
(1.17)\end{array}$ & $\begin{array}{l}-0.945 \\
(1.16)\end{array}$ & $\begin{array}{r}-0.942 \\
(1.17)\end{array}$ & $\begin{array}{l}-0.930 \\
(1.17)\end{array}$ \\
\hline Strong preferences for redistribution & $\begin{array}{c}0.291^{* *} \\
(0.12)\end{array}$ & $\begin{array}{c}0.285^{* *} \\
(0.12)\end{array}$ & $\begin{array}{c}0.293^{* *} \\
(0.12)\end{array}$ & $\begin{array}{c}0.285^{* *} \\
(0.12)\end{array}$ & $\begin{array}{c}0.294^{* *} \\
(0.12)\end{array}$ & $\begin{array}{c}0.281^{* *} \\
(0.12)\end{array}$ \\
\hline Perceived sanction & $\begin{array}{l}0.027 \\
(0.02)\end{array}$ & $\begin{array}{l}0.021 \\
(0.02)\end{array}$ & $\begin{array}{l}0.027 \\
(0.02)\end{array}$ & $\begin{array}{l}0.028 \\
(0.02)\end{array}$ & $\begin{array}{l}0.028 \\
(0.02)\end{array}$ & $\begin{array}{l}0.028 \\
(0.02)\end{array}$ \\
\hline Peer effects & $\begin{array}{c}0.326^{* * *} \\
(0.07)\end{array}$ & $\begin{array}{c}0.327^{* * *} \\
(0.07)\end{array}$ & $\begin{array}{c}0.324^{* * *} \\
(0.07)\end{array}$ & $\begin{array}{c}0.322^{* * *} \\
(0.07)\end{array}$ & $\begin{array}{c}0.324^{* * *} \\
(0.07)\end{array}$ & $\begin{array}{c}0.320^{* * *} \\
(0.07)\end{array}$ \\
\hline Random-effects & & & & & & \\
\hline Country level (estimate/se) & $\begin{array}{c}0.000 \\
(0.489)\end{array}$ & $\begin{array}{c}0.000 \\
(0.441)\end{array}$ & $\begin{array}{c}0.000 \\
(0.564)\end{array}$ & $\begin{array}{c}0.000 \\
(0.501)\end{array}$ & $\begin{array}{c}0.000 \\
(0.5282)\end{array}$ & $\begin{array}{c}0.000 \\
(0.721)\end{array}$ \\
\hline City level (estimate/se) & $\begin{array}{c}0.769 \\
(0.167) \\
\end{array}$ & $\begin{array}{c}0.764 \\
(0.166) \\
\end{array}$ & $\begin{array}{c}0.792 \\
(0.170) \\
\end{array}$ & $\begin{array}{c}0.791 \\
(0.170) \\
\end{array}$ & $\begin{array}{c}0.796 \\
(0.170) \\
\end{array}$ & $\begin{array}{c}0.821 \\
(0.174) \\
\end{array}$ \\
\hline$N$ & 3,225 & 3,225 & 3,225 & 3,225 & 3,225 & 3,225 \\
\hline$F-$ Statistic & $73.63^{* * *}$ & $73.93^{* * *}$ & $76.99 * * *$ & $78.58^{* * *}$ & $75.64^{* * *}$ & $80.84^{* * *}$ \\
\hline
\end{tabular}

Note: Immunizations coverage (POL3) refers to the percentage of surviving infants who receive the 3rd dose of polio containing vaccine as estimated by WHO-UNICEF. Tax burden as \% GDP as calculated by the Inter-American Development Bank (IADB) and the Inter-American Center of Tax Administrations (CIAT). Income taxation as \% GDP includes Personal Income Tax and Corporate Income Tax as as calculated by the Inter-American Development Bank (IADB) and the Inter-American Center of Tax Administrations (CIAT). All the figures were estimated for 2011-2012. Significance levels: ${ }^{*} p<0.10,{ }^{* *} p<0.05$, *** $p<0.01$ 


\section{Interaction models}

Table A.8: Is tax evasion morally justifiable? Latin America, 17 cities. Interaction models

\begin{tabular}{|c|c|c|c|}
\hline & $\begin{array}{c}(1) \\
\text { Baseline } \\
b /(s e)\end{array}$ & $\begin{array}{c}(2) \\
\text { Interaction } \\
\text { income } \\
b /(s e) \\
\end{array}$ & $\begin{array}{c}(3) \\
\text { Interaction } \\
\text { preferences } \\
b /(s e)\end{array}$ \\
\hline Private health insurance & $\begin{array}{c}0.479^{* *} \\
(0.24)\end{array}$ & $\begin{array}{l}0.349 \\
(0.30)\end{array}$ & $\begin{array}{c}0.679^{* *} \\
(0.31)\end{array}$ \\
\hline Household income & $\begin{array}{r}-0.000 \\
(0.00)\end{array}$ & $\begin{array}{r}-0.000 \\
(0.00)\end{array}$ & $\begin{array}{r}-0.000 \\
(0.00)\end{array}$ \\
\hline Education & $\begin{array}{l}-0.038 \\
(0.03)\end{array}$ & $\begin{array}{l}-0.038 \\
(0.03)\end{array}$ & $\begin{array}{l}-0.037 \\
(0.03)\end{array}$ \\
\hline In the labor market & $\begin{array}{l}-0.943 \\
(1.17)\end{array}$ & $\begin{array}{c}-0.944 \\
(1.17)\end{array}$ & $\begin{array}{l}-0.933 \\
(1.17)\end{array}$ \\
\hline Strong preferences for redistribution & $\begin{array}{c}0.294^{* *} \\
(0.12)\end{array}$ & $\begin{array}{c}0.291^{* *} \\
(0.12)\end{array}$ & $\begin{array}{c}0.327^{* *} \\
(0.13)\end{array}$ \\
\hline Perceived probability of sanction & $\begin{array}{l}0.027 \\
(0.02)\end{array}$ & $\begin{array}{l}0.027 \\
(0.02)\end{array}$ & $\begin{array}{l}0.026 \\
(0.02)\end{array}$ \\
\hline Peer effects & $\begin{array}{c}0.324^{* * *} \\
(0.07)\end{array}$ & $\begin{array}{c}0.323^{* * *} \\
(0.07)\end{array}$ & $\begin{array}{c}0.325^{* * *} \\
(0.07)\end{array}$ \\
\hline Private insurance*income & & $\begin{array}{l}0.000 \\
(0.00)\end{array}$ & \\
\hline Private insurance*redistribution & & & $\begin{array}{l}-0.415 \\
(0.45)\end{array}$ \\
\hline $\begin{array}{l}\text { Random-effects } \\
\text { Country level (estimate/se) }\end{array}$ & $\begin{array}{c}0.000 \\
(0.619)\end{array}$ & $\begin{array}{c}0.000 \\
(0.622)\end{array}$ & $\begin{array}{c}0.000 \\
(0.610)\end{array}$ \\
\hline City level (estimate/se) & $\begin{array}{c}0.796 \\
(0.171)\end{array}$ & $\begin{array}{c}0.793 \\
(0.171)\end{array}$ & $\begin{array}{c}0.793 \\
(0.171)\end{array}$ \\
\hline$N$ & 3,225 & 3,225 & 3,225 \\
\hline$F-$ Statistic & $41.22^{* * *}$ & $41.46^{* * *}$ & $41.98^{* * *}$ \\
\hline
\end{tabular}




\section{Interaction insurance scheme and occupation}

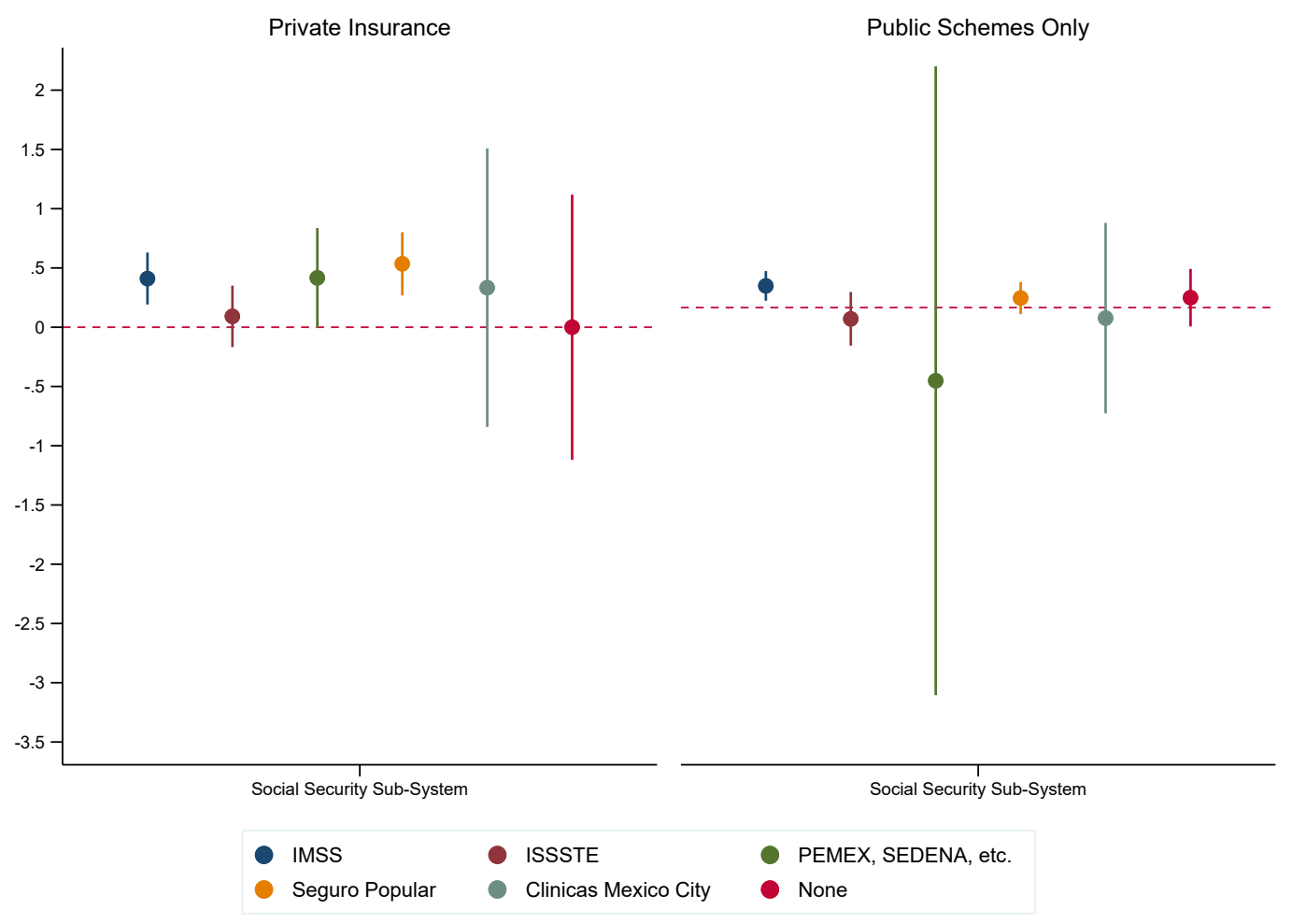

Figure A.2: Willingness to evade taxes by type of health care provider and access to different social security institutions, Mexico City, 2017. Based on list experiment, linear estimators, Table 2 . 


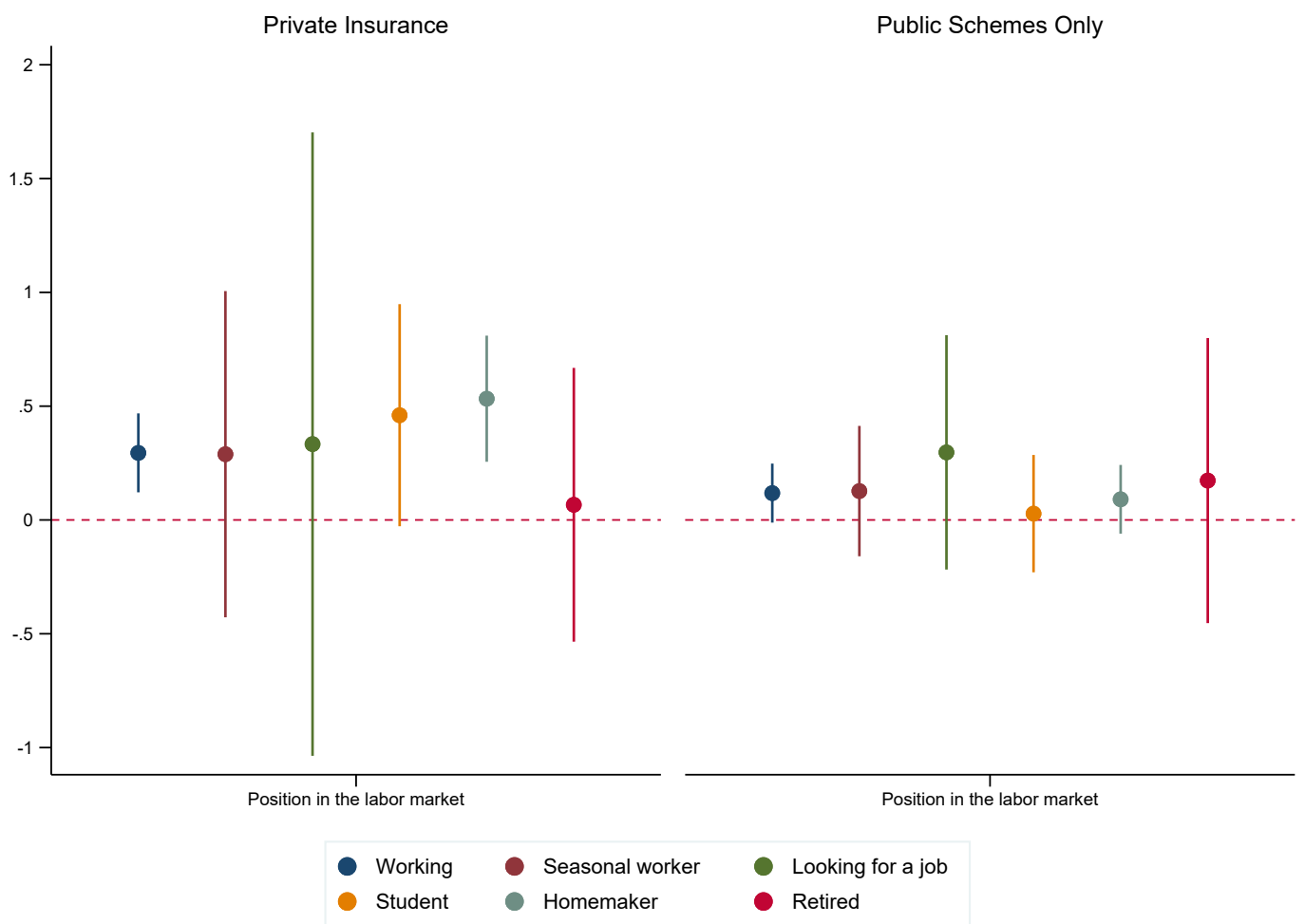

Figure A.3: Willingness to evade taxes by type of health care provider and occupation, Mexico City, 2017. Based on list experiment, linear estimators, Table 2. 